\title{
TESES DE DOUTORADO E DISSERTAÇÕES DE MESTRADO DEFENDIDAS
}

(Maio de 2009 a Novembro de 2010)

\section{Teses de Doutorado}

\section{Os lavradores da floresta: um estudo sobre as contradições das políticas públicas de conservação na proteção do modo de vida tradicional.}

Cristina de Marco Santiago

\section{Orientador: Adyr Apparecida Balastreri Rodrigues}

Este trabalho teve por objetivo aprofundar a reflexão e a compreensão sobre a lógica da relação sociedade-natureza nas culturas tradicionais, bem como sobre as contradições existentes nas políticas públicas territoriais de conservação da natureza, no que se refere à valorização do modo de vida tradicional. A pesquisa foi realizada a partir da análise dessas políticas e do estudo de um bairro rural tradicional caipira, o bairro dos Paulo, localizado no município de Ibiúna - São Paulo, na área de abrangência do Parque Estadual do Jurupará. O estudo de caso apresentou os elementos empíricos necessários para aprofundar a compreensão da problemática tratada pela pesquisa, ou seja, a maneira pela qual se processaram os conflitos sociais, em um contexto histórico, entre dois tipos de racionalidade e de modo de vida: um rural tradicional e, outro, contemporâneo, urbano-industrial. O desenvolvimento da pesquisa em campo se deu segundo o método da pesquisa participante, adotando-se a entrevista semiestruturada como instrumento de coleta de dados. A análise dos documentos legais e das entrevistas foi realizada com base no método de análise textual discursiva. Foi efetuado ainda o estudo comparativo do uso do solo, das glebas pertencentes à família dos Paulo, em diferentes momentos históricos: 1962, 1978 e 2009, a partir de dados secundários e de fotografias aéreas. Trata-se de um estudo geográfico de abordagem cultural crítica, em que foram definidas três categorias centrais de análise foram definidas: o território, o modo de vida tradicional e as políticas públicas territoriais de conservação da natureza. Categorias estas que, articuladas, possibilitaram identificar as formas de adaptação e a alta capacidade de resistência da cultura caipira frente aos impactos a que foi submetida, particularmente, com as transformações advindas do progresso brasileiro e, posteriormente, com a investida do Estado em criar uma Reserva Florestal, posteriormente transformada em um Parque Estadual em território caipira. A pesquisa demonstrou que os territórios tradicionais se configuram a partir de uma conduta ética diferenciada na relação sociedade-natureza. O modo de vida tradicional reflete saberes e valores que configuram um tipo específico de território, onde sua permanência no tempo, ao longo de sucessivas gerações, bem como a conservação da natureza são condições para a reprodução material e social das chamadas populações tradicionais. Na sua construção histórica, enquanto patrimônio territorial, delineiase um tipo de gestão e de planejamento específicos, onde princípios, normas, critérios, formas de comando e hierarquias existem calcados em uma forte condição de autonomia, 
características estas incompatíveis com as diretrizes legais estabelecidas nos territórios de conservação da natureza. Território e modo de vida foram categorias a partir das quais se pôde, ainda, neste estudo, delinear dez premissas para a atuação do Estado junto aos territórios tradicionais caipiras, segundo seus próprios padrões de desenvolvimento, sem o que se entende que não há como falar em reconhecimento e respeito ao modo de vida tradicional. A coerência destas premissas foi discutida tendo-se por referência modelos teóricos de desenvolvimento econômico, considerados compatíveis com as características do território tradicional.

\section{Urbanização e educação: da escola de bairro à escola de passagem}

\section{Gilberto Cunha Franca}

Orientador: Odette Carvalho de Lima Seabra

Esta pesquisa aborda a relação da escola pública com a geografia dos lugares. Analisa os nexos entre a urbanização e as políticas educacionais em São Paulo. A questão consiste em compreender a situação das escolas centrais, que pertenceram aos antigos bairros, diante das adequações funcionais e do desinteresse das camadas médias e altas. As localidades centrais foram tradicionalmente compreendidas como espaços da cidade-bairro, da cidade subúrbio. Na dinâmica da urbanização difusa, e de ampliação das fronteiras periféricas, estas localidades centrais vivenciaram o esvaziamento generalizado e o fechamento de dezenas de suas escolas. Paradoxalmente, isto tem ocorrido onde as escolas públicas apresentam melhor desempenho. $O$ fechamento destas escolas restringe as possibilidades dos moradores locais e inviabiliza o uso dos alunos que vêm das periferias urbanas. Neste contexto o terreno destas antigas escolas ficou na mira do mercado imobiliário e das estratégias administrativas do Estado. $O$ estudo de caso da EE Prof. Antonio Alves Cruz permitiu apreender a metamorfose da escola de bairro, e seu dilema para sobreviver no centro da cidade.
Encontrou solução na ampliação do seu raio de ação, atingindo pontos distintos da metrópole; no seu momento mais dramático incorporou uma Organização Não Governamental para realizar atividades que seriam difíceis com a estrutura da rede oficial; adequou-se a diversas modalidades de ensino; aceitou diversas formas de uso. Em alguns momentos seus personagens se encontram, porém, o que ressalta é o quadro preocupante de desintegração da comunidade escolar, que a deixa vulnerável perante os ajustes dos órgãos superiores de ensino.

\section{O ensino de geografia na educação básica: os desafios do fazer geográfico no mundo contemporâneo}

\section{Gliceide Rodrigues da Silva}

Orientador: Francisco Capuano Scarlato

A pesquisa intitulada o ensino de geografia na educação básica: os desafios do fazer geográfico no mundo contemporâneo toma a fenomenologia como método de investigação para o ensino de geografia no nível médio a partir de uma análise pautada na descrição da realidade, colocando no centro da reflexão o próprio ser, o ser aluno, o ser professor, ser humano, descrevendo o cotidiano escolar. No pensamento fenomenológico não existe um mundo sem sujeito, tampouco um sujeito sem mundo. E ainda pensar que não existe um sujeito sem espaço e ressalta-se, não é qualquer espaço, mas o espaço vivido. Então, para compreender o ensino de geografia, adotamos uma ação de intencionalidade, pois este é um dos pressupostos para se entender a fenomenologia, a partir de uma consciência intencional. Desse modo, a pesquisa se alinha aos pressupostos da geografia cultural para uma análise do potencial da escola, a partir da identidade com/no lugar, onde nasce a cidadania, capaz de possibilitar a compreensão do mundo vivido no ensino de geografia, o lugar, onde efetivamente as pessoas vivem, onde o passado e o presente se manifestam no espaço e na memória das pessoas, onde as relações de vizinhanças e de conflitos são estabelecidas, onde os jovens desenvolvem 
atividades de lazer e eventos culturais. Compreendemos o território como sinônimo de espaço vivido, apropriado, usado, delimitado que configuram os aspectos políticos, econômicos e culturais. Assim, em consonância com as novas formas de compreensão da geografia cultural, abordamos o ensino de geografia na educação básica, permitindo uma compreensão do mundo contemporâneo. A pesquisa utilizou como instrumentos de análise, dados primários, como os relatórios de estágios supervisionados desenvolvidos na disciplina de prática de ensino de geografia, nos anos escolares do nível médio da Escola de Ensino Fundamental e Médio Ministro Jarbas Passarinho, da rede pública estadual do município de Sobral - Ceará. A pesquisa considera que é preciso tornamos organizadores de aprendizagens, de aprendizagens por via dos novos meios informáticos, por via dessas novas realidades virtuais e reais. Mostrarmos que a competência do fazer geografia está associada à sua compreensão do conhecimento, compreender a ponto de reorganizar, de ser capaz de reelaborar e de transpô-lo em situação didática em sala de aula.

\section{Migração e reprodução social: tempos e espaços do cortador de cana e de sua família}

\author{
Lucia Cavalieri
}

\section{Orientador: Marta Inez Medeiros Marques}

Esta pesquisa tem por objetivo entender como ocorre o processo contraditório da reprodução social das comunidades rurais à luz de uma análise das práticas cotidianas e das estratégias de reprodução social da família do migrante, cortador de cana do Vale do Jequitinhonha. Os homens migrantes vivem ora mais próximos da condição camponesa, ora sorvidos como proletários na cana. Não se realizam plenamente em nenhuma das duas condições. No território da cana estão proletários; no território camponês não têm mais terras para o trabalho e a família não conta com os homens em suas práticas cotidianas. Esses camponeses-migrantes encontram-se na margem.
A pesquisa de campo se realizou em duas comunidades rurais: Alfredo Graça e Engenheiro Schnoor localizadas no município de Araçuaí, no Vale do Jequitinhonha. Estas comunidades têm algumas características comuns: a migração dos homens para o corte de cana em São Paulo e uma série de custos imputados à família, em especial às suas mulheres. Nosso interesse consiste em entender como esse sujeito, na condição de camponês-migrante, perdura no tempo e quais são as fissuras que essa condição provoca em sua família e em seu território.

\section{Um homem, um lugar: geografia da vida e perspectiva ontológica}

\author{
Samarone Carvalho Marinho
}

$$
\text { Orientador: Júlio César Suzuki }
$$

Este trabalho tem por objetivo estudar as determinações geográficas da objetivação humana concernentes às realizações dos indivíduos manifestadas relativamente na objetivação poética. Para tanto, no nível de crítica expositiva, revela-se uma perspectiva capaz de contemplar a relação de objetivação entre homem e lugar. Apresenta-se então a perspectiva ontológica que, em sustentação ao temário que compõe a Geografia da vida, privilegia a busca pelas relações de objetivações inerentes às realizações humanas, as artísticas algumas delas. Num momento posterior, no nível de análise compreensiva, aderente à crítica expositiva, demonstra-se a operacionalização do temário utilizando como veículo da idéia o estudo geográfico do homem em suas três dimensões (corporeidade, individualidade, socialidade). A partir de tal estudo expõe-se uma relação objetivadora de um ser consciente de geograficidade indivisa (Ferreira Gullar) com específico espaço de existência (Buenos Aires) produtora, de maneira coparticipativa, dos efeitos estéticos a uma especial objetivação humana (o Poema sujo). Ao se tomar de empréstimo o método progressivoregressivo quer-se mostrar certo equilíbrio tensivo ao registro ontológico da gênese da objetivação poética. Assim, no âmbito da análise, ao longo do 
Teses de Doutorado e Dissertações de Mestrado

trabalho, aprofunda-se o "vaivém" (o ir e vir) entre um lugar (Buenos Aires) e um homem (Ferreira Gullar) com intuito de se buscar as determinações geográficas evidenciadoras do fenômeno estético (Poema sujo). Por meio de cisão respeitosa das instâncias (sociopolítica, econômica, cultural), chega-se a um quadro crítico-existencial da realização poética (Poema sujo) de determinado poeta (Ferreira Gullar). Por fim, em termos de evidência empírica, evidencia-se uma realização poética em que um poeta brasileiro regride, em exílio, à esfera de significados aderentes à Argentina pretérita (1976-1983) para, em relação a esta, recolocar a si próprio no impulso histórico globalizante, aprofundando a época e a própria objetivação poética.

\section{Sistema de indicadores e desigualdade socioambiental intraurbana de São Luis - MA}

\section{Zulimar Márita Ribeiro Rodrigues}

Orientador: Wagner Costa Ribeiro

Aplicação de um sistema de indicadores intraurbano à cidade de São Luís para mensurar a sua desigualdade socioambiental. Como instrumentos para medir e informar sobre as cidades, os indicadores urbanos podem ser classificados em: indicadores intermunicipais e intramunicipais. Com base nesta divisão, utilizase a escala intraurbana para propor um sistema de indicadores aplicado à capital maranhense, subdividido em quatro dimensões: habitabilidade, saneamento, educação e renda. Para compor os indicadores das respectivas dimensões, foram utilizados os dados secundários do censo IBGE/ 2000, desagregados ao nível dos 780 setores censitários de São Luís (MA). A análise estatística dos dados é fundamentada em técnicas multivariadas, a saber: Análise Fatorial $(A F)$ e Análise de Clusters ( $A C)$. A primeira técnica permitiu resumir e reduzir os dados censitários, sem perda significativa das informações originais. A segunda técnica proporcionou a definição e a agregação dos setores censitários em quatro clusters distintos. Com os resultados estatísticos dos indicadores que componham cada uma das quatro dimensões, os clusters identificados foram mapeados e comparados entre si para dimensionar a desigualdade intraurbana. Na dimensão habitabilidade, avaliou-se dois aspectos: padrão de moradia e o acesso à propriedade. Observouse que não há grandes desigualdades intraurbanas na dimensão habitabilidade. A segunda dimensão foi o saneamento, com ênfase em três subdimensões: abastecimento de água, rede coletora de esgotos e de lixo. Nesse tópico a maior desigualdade intraurbana está relacionada ao serviço de coleta de esgotos, seguido do serviço de coleta de lixo e abastecimento de água. $\mathrm{Na}$ dimensão educação, abordaram-se duas subdimensões: alfabetização da população por faixa etária e escolaridade do responsável pelas residências. As desigualdades intraurbanas não revelaram grandes discrepâncias quanto aos indicadores educacionais entre os quatro clusters na cidade, exceto para a subdimensão, escolaridade do responsável com 15 anos de estudo, sobretudo, quando comparado às áreas norte e sul do espaço urbano. A dimensão renda do responsável foi o tópico que revelou a maior discrepância intraurbana em relação às demais dimensões avaliadas e entre os clusters. Através do sistema de indicadores intraurbanos, proposto para São Luís, concluiu-se que espaço urbano é desigual social e ambientalmente. As diferenças internas da cidade foram avaliadas e cartograficamente representadas, utilizou-se para elaboração dos mapas, o programa ArcGIS versão 9.3.

\section{Geografia Política e os recursos hídricos compartilhados: o caso Israelo-Palestino}

\author{
Gilberto Souza Rodrigues Junior
}

$$
\text { Orientador: Wagner Costa Ribeiro }
$$

O trabalho aqui apresentado busca analisar a centralidade dos recursos hídricos no conflito israelo-palestino e em suas negociações de paz, no que diz respeito à configuração territorial tanto do Estado de Israel quanto de um possível Estado Palestino, a partir da perspectiva da Geografia 
Política. Partindo desse pressuposto busca discutir questões relacionadas à segurança internacional, à soberania dos Estados, e uma suposta mudança de paradigmas em relação a esses temas a partir da emergência das questões ambientais nas últimas décadas. A discussão acerca das possibilidades de conflitos envolvendo recursos hídricos é de grande relevância. Assim, analisar esse assunto tendo como área de estudo o Estado de Israel e os Territórios Ocupados da Palestina, acrescenta ao tema elementos de maior dramaticidade, devido a diversos fatores tais como a pouca oferta hídrica e a importância estratégica da região, o que decorre de fatores de ordem econômica, política e cultural. A partir de tal recorte regional, foi feita uma análise do conflito num constante variar de escalas, possibilitando assim, compreender os eventos locais desde uma perspectiva da totalidade, de forma que essa compreensão possa servir também como base para estudos de ordem global. Foi possível perceber as dificuldades encontradas pelo povo palestino, bem como as preocupações do Estado de Israel em relação à sua segurança hídrica. A água se torna então um elemento político na disputa por territórios e também nas mesas de negociações do conflito

\section{O uso do território brasileiro e as instituições de ensino superior}

\section{Cassiano Caon Amorim}

\section{Orientador: Maria Adélia Aparecida de Souza}

O presente estudo defende o pressuposto de que a localização específica das Instituições de Ensino Superior, no processo de formação territorial brasileira, comprova que a seletividade espacial representa a ação dada em lugares escolhidos pelos agentes sociais. Com formas e conteúdos bastante diferenciados, com variadas densidades humanas, o território brasileiro, no tempo presente, encontra-se inteiramente apropriado. Ainda que de forma bastante desigual quanto à sua distribuição, constata-se, num crescente número de lugares, maior densidade técnica acompanhada de maior densidade informacional.
Trata-se de constatações concretas quando comparamos o crescimento de modernizações em parcelas do território que, até recentemente, encontravam-se pouco conectadas a outros subespaços do país. O crescimento do número de instituições de ensino superior, em cidades fora das regiões metropolitanas e com mais de 100 mil habitantes, sinaliza para o fato de uma interiorização desse evento, correspondendo a uma verdadeira conquista do território. É importante destacar que, nesse movimento, embora o que se amplia seja uma demanda por qualificações específicas em todo o território, a oferta de vagas em tais instituições acompanha as especializações produtivas dos lugares. Em consonância com as necessidades do período técnico-científico-informacional, o ensino superior desenvolve-se de forma que suas ofertas ajudam a configurar o território. É nesse contexto que compreendemos a realidade de Juiz de Fora/MG: historicamente, a cidade aglutina fixos favorecendo fluxos que, por conseguinte, impulsionaram a atração de investimentos, de pessoas, de instituições, enfim. Ratificando a tese que defendemos, a cidade exibe, portanto, o processo de seletividade espacial na alocação de instituições de ensino superior.

\section{Divisão do trabalho e circuitos da economia urbana em Londrina - PR}

\section{Edilson Luís de Oliveira}

\section{Orientador: Maria Laura Silveira}

O objetivo central desta tese é analisar as transformações da economia urbana londrinense, particularmente de seu circuito inferior, à luz das variáveis que caracterizam o período atual, o período da globalização. Para tanto, dividimos a presente tese em duas partes. Na primeira, analisamos as sucessivas modernizações efetivadas em Londrina e as transformações na divisão territorial do trabalho que redundaram em diferentes especializações produtivas a partir da década de 1930. Na segunda parte, analisamos a organização e o funcionamento de três atividades do circuito inferior da economia urbana: o pequeno 
Teses de Doutorado e Dissertações de Mestrado

comércio estabelecido no Camelódromo de Londrina, o serviço de Mototáxi e o serviço de Entregas Urbanas realizado por motoboys. As conclusões a que chegamos revelam que, no período atual, a dinâmica do meio construído é um dado fundamental da economia urbana. Os fluxos que se efetivam a partir das atividades investigadas envolvem a redefinição dos papéis de intermediação que caracterizam Londrina como uma cidade média da Região Concentrada. O circuito inferior atual apresenta diferenças importantes em relação àquele que se formou em Londrina ao longo dos anos 1970, tais como: as trajetórias dos trabalhadores no mercado de trabalho, a importância dos processos migratórios do campo para a cidade, as escalas de ação de cada circuito, suas formas de integração, entre outras. Estas diferenças são conseqüências das modernizações na economia urbana inerentes à expansão e difusão espacial do meio técnicocientífico-informacional.

\section{O professor de Geografia e os saberes profissionais: o processo formativo e o desenvolvimento da profissionalidade}

\section{Claudivan Sanches Lopes}

\section{Orientador: Nidia Nacib Pontuschka}

Esta tese trata do processo de apropriação, produção e desenvolvimento dos conhecimentos/ saberes necessários à docência em Geografia. Considerando a especificidade desse campo disciplinar no currículo escolar, busca identificar e apreender aqueles conhecimentos/saberes que professores de Geografia, ao atuarem na Educação Básica, devem dominar para desenvolver um trabalho pedagógico-geográfico que promova aprendizagens significativas e edifique sua profissionalidade. No bojo das pesquisas que têm por escopo a profissionalização dos professores e seu principal corolário, os saberes docentes, pretende-se contribuir, de maneira geral, para o reconhecimento e maior valorização social do trabalho docente e, particularmente, com a melhoria dos processos de formação do professor de Geografia. Para tanto, além de pesquisa bibliográfica, que focaliza esse campo de investigação, obtiveram-se dados e informações em observações de aula e entrevistas com cinco professores experientes e especialistas nessa área do currículo escolar que atuam no município de Maringá, PR. Orientados pela metodologia de análise de conteúdo, foi construído um conjunto de categorias para explicitar, de acordo com os objetivos propostos, os resultados alcançados. Verificou-se que o olhar global dos professores de Geografia sobre seu trabalho e profissão carrega as marcas do campo disciplinar. Os professores percebem que a afirmação do discurso geográfico, seus temas, conceitos e procedimentos no currículo escolar são importantes para o fortalecimento não somente da identidade da disciplina, como da própria profissionalidade. Eles se definem como professores em seu sentido mais genérico, mas buscam-se reconhecer e serem reconhecidos como professores de Geografia. Nesse movimento, apropriam-se de uma determinada tradição geográfica escolar que, alimentada pelo desenvolvimento histórico da ciência de referência e pelo próprio saber produzido e acumulado pela experiência profissional, é avaliada, criticada e recriada continuamente. Constatou-se, assim, que o processo de reflexão pedagógica que os professores desenvolvem com o intuito de tornar acessível, atraente e útil aos alunos os conhecimentos geográficos selecionados pelo currículo não ocorre à margem da natureza dos temas e conteúdos. Destaca-se que, ao se envolverem nesta complexa tarefa, os professores produzem saberes profissionais específicos, categorizados na literatura educacional como Conhecimento Pedagógico do Conteúdo e que, nesta tese, entende-se ser adequado denominálo de conhecimento pedagógico geográfico. No ato docente, o conhecimento geográfico e de ciências afins, conhecimentos pedagógicos gerais e conhecimentos do contexto da ação educativa notadamente da vivência dos alunos se mesclam e dão origem ao conhecimento pedagógico geográfico. Esse tipo de conhecimento é, sem dúvida, um sinal evidenciador da compreensão especial dos conteúdos que uma docência de qualidade exige e revela, também, o 
desenvolvimento da profissionalidade docente. Entre as estratégias relativas ao seu processo formativo e, especialmente, na formação inicial, ficou evidenciada a necessidade de conceber e implementar uma arquitetura curricular que proporcione aos futuros professores uma compreensão orgânica da relação entre conhecimentos específicos da Geografia e os conhecimentos pedagógicos e, ao mesmo tempo, oferecer-lhes meios adequados para 0 desenvolvimento de disposições que os levem a conceber e desenvolver uma docência sensível aos diversos contextos sociogeográficos da prática profissional do professor.

\section{Contribuição ao estudo do poder local em Osasco: um estudo geográfico-político}

\section{Celso Roberto de Brito}

\section{Orientador: José William Vesentini}

A cidade de Osasco, que faz parte da Região da Grande São Paulo, possui uma superfície de 64,94 $\mathrm{Km}^{2}$, uma população absoluta de 701.012 habitantes e 478.190 eleitores (IBGE, 2007). A origem da cidade de Osasco deve-se realmente a um italiano de nome Antônio Giuseppe di Pietro Agu, funcionáriol da Estrada de Ferro Sorocabana, que em 1893 comprou uma gleba de terra compreendida entre os córregos Bussocaba e Aguadinha, e tornou-se fornecedor da Estrada de Ferro Sorocabana, à qual vendia areia, telhas e tijolos. É cortada no sentido leste oeste pelo rio Tietê, cujo vale foi aproveitado para construir o traçado da Estrada de Ferro Sorocabana, responsável pelo nascimento da nossa cidade. A localização de Osasco, próxima à capital, mais as facilidades apresentadas por ser servida pela ferrovia, contribuíram para o desenvolvimento da região, pois esses fatores atraíram para cá grande número de empresários e trabalhadores, incentivando o progresso e o desenvolvimento. A cidade de Osasco se torna, cada vez mais, um espaço que se organiza para abrigar as grandes empresas, isso reduz os recursos públicos possíveis de serem destinaddos à população, agravando a crise social. Costuma-se considerar no Brasil a existência de dois principais tipos de poder local: o tradicional (coronelismo) e o moderno (dinâmica de lutas, com a participação da sociedade civil). O caso de Osasco, hoje, é o de um poder local moderno e complexo. O poder local, com os seus instrumentos básicos, que são a participação comunitária e o planejamento descentralizado, constitui, nesse sentido, um mecanismo de ordenamento político e econômico que já deu provas de eficiência nos países desenvolvidos. Ele é sem dúvida o grande recurso subutilizado na nossa cidade.

\section{Escala de análise e cartografia: estudo da representação gráfica de fenômenos complexos, no âmbito da ciência geográfica}

Marta de Paiva Macêdo

Orientador: Marcello Martinelli

Neste estudo, partimos do pressuposto de que o conhecimento dos fenômenos da realidade, em seu aspecto qualitativo, são manifestações de seu conteúdo que devem estar à frente de qualquer processo de apreensão apoiado em bases quantitativas, em que pese ser este uma necessidade ao conhecimento, demandada pela possibilidade de reconhecimento do real por sua estrutura. O conhecimento do específico pressupõe, em nosso entender, a particularidade que assume força de compartilhamento ou relações específicas entre o ser social e a espacialidade produzida. Espaço geográfico é, assim, o resultado de processos sempre inacabados da realidade, e, a região é nesse sentido, um reflexo de espacialidade provisória. A região é entendida neste estudo como fenômeno complexo, devendo ser compreendida através da incerteza que caracteriza o real, e que como realidade precisa ser compreendida. $\mathrm{E}$, uma forma admitida para isto, é o mapa, tido como instrumento capaz de sintetizar o que os conteúdos da apreensão do aspecto regional, a partir do real, refletem. Desse modo, o processo de apreensão de tais conteúdos pensados à luz de conceitos geográficos de região, e, consubstanciados por uma Teoria do 
Teses de Doutorado e Dissertações de Mestrado

Conhecimento, com vistas à sua representação em mapa, foi o que, de certo modo, nos conduziu no percurso deste estudo. Entender a região, não foi objetivo principal aqui, mas a força dos diversos conceitos que a representa. Essa pluralidade conceitual e a persistência destes, ao lado das teorias que os fundamentam, terminam por influenciar várias escolhas na sua cartografia. A força dos conceitos a que nos referimos aqui, está em sua dimensão empírica, portanto, na realidade. Para tanto, a realização cartográfica depende da escala de apreensão do fenômeno. A escala no nível conceitual é para o fenômeno da região, o alcance da manifestação regional, o ponto de partida admitido a que este estudo se refere a região compreendida a partir da realidade empírica. Encontra-se desse modo, como solução mais adequada às cartografias da região, a forma de entendimento que cada pesquisador admite no exercício da reflexão sobre a realidade, cuja consciência e compromisso com critérios de verdade, conferem ao lado dos instrumentos técnicos, a conformação do aspecto regional. Ressalta-se, entretanto, que limitações próprias do processo de conhecimento, o seu caráter estruturador e generalizador, associadas aos métodos cartográficos que privilegiam funções automáticas nesse processo, terminam por elaborar um mapa inadequado. Contudo, o método para a solução disso repousa, em nosso entender entre a síntese do concreto pensado e a síntese cartográfica, designada nesse estudo de esforço de totalidade, ou ainda, síntese raciocinada. Esse método, entretanto, caracteriza-se por refutar veementemente critérios quantitativos apenas, como ponto de partida da realização cartográfica, às vezes, desprezando aspectos qualitativos. Além disso, consideramos que a força da razão mobiliza tais aspectos qualitativos na apreciação crítica da realidade pelo sujeito cognoscente, e que está em sua intenção as motivações do fazer cartográfico. Desse modo, as limitações próprias da estruturação do conhecimento não participam tão ativamente da escolha dos conteúdos a serem considerados na cartografia para a Geografia. Isto se dá pela consciência de que somos influenciados por uma dimensão da realidade que não é geométrica. Assim, o esforço de totalidade pode validar a concepção do mapa da realidade complexa, desde que se priorize uma leitura qualitativa, e que não se prescinda da eleição de um conceito de região ancorado na dimensão empírica da realidade, como procedimento que anteceda a todo o processo.

\section{Evolução urbana e dinâmica da paisagem em setores periféricos da metrópole paulistana: o caso de Taboão da Serra - SP}

\author{
Wellison Tatagiba de Araújo \\ Orientador: Adilson Avansi de Abreu
}

A pesquisa tem por objetivo, analisar as influências da urbanização concentrada (compacta), e de como essa característica altera as condições ambientais e o equilíbrio das formas de relevo local , modificando o estrato geográfico da paisagem. Para essa análise tivemos como supor te o mapeamento da evolução do uso da terra urbana em Taboão da Serra em dois momentos distintos, no período compreendido entre 1962 e 2007 . O uso da terra tem contornos distintos no contexto intraurbano, fato este que é traduzido pela evolução e pelo tipo de uso e ocupação dado à paisagem urbana em Taboão da Serra. Os processos geoecológicos encontram- se modificados na sua gênese e na sua estrutura, o que resulta em formas mais antropizadas do que em décadas passadas. A cidade de Taboão da Serra, é a sexta cidade mais compacta do Brasil, fato este que tem reflexos negativos sobre os processos naturais onde, a morfogênese é dominante por conta do intenso uso da terra seja ele para fins imobiliários como também pelo processo de intensificação da cobertura da superfície por materiais que interrompem a percolação das águas pluviais associado à retirada da cobertura vegetal. A escolha da cidade como área de estudo deu-se pelos motivos explicitados acima mas também, pelo fato de que através da comparação de dois momentos da ocupação urbana (1962 e 2007) que são caracterizadas pela intensificação do uso da terra (utilizando fotografias aéreas ), é possível mapear e representar como o tipo de uso e ocupação pode comprometer em maior ou menor grau as 
condições geoecológicas de um geossistema. As unidades de paisagem urbana serão compartimentadas tendo como final idade a comparação para diagnosticar a relação atual entre relevo/ solo e uso da terra nesta c idade, que serão representadas na carta de Uso da Terra.

\section{Variabilidade climática e sua influência na produtividade da cultura da cana-de-açúcar (Saccharum spp) na região norte e noroeste do Paraná}

\section{Ivonete de Almeida Souza Domingues}

\section{Orientador: Emerson Galvani}

A atividade agrícola é essencialmente importante para o estado do Paraná, onde a região deste estudo é a porção Norte e Noroeste, representadas pelos municípios de Cambé e Mirador. Regiões estas localizadas sob solos distintos, argilosos e arenosos, respectivamente. Nessas se destacam o cultivo da cana-de-açúcar, objeto deste estudo, por apresentar condições climáticas mais favoráveis ao seu ciclo vegetativo, que tem duração que varia de 12 a 18 meses. Sendo a variabilidade dos controles do clima um fator influenciador principalmente da sua produtividade. Essa cultura exige duas estações meteorológicas bem definidas, uma quente e úmida no estádio de desenvolvimento vegetativo e outra seca ou fria no estádio de maturação. As necessidades térmicas e hídricas são em torno de $20^{\circ}$ a $30^{\circ} \mathrm{C}$ e em torno de 1000 milímetros. Assim, esta tese teve por objetivo determinar a relação entre a variabilidade térmica, hídrica e produtividade do cultivo da cana-de-açúcar para o período de 1981/ 82 a 2005/06. Os procedimentos metodológicos destinaram-se a evolução espaço-temporal da cana-de-açúcar; à dinâmica climática dos controles chuva e temperatura; à contabilização do Balanço Hídrico (BH Normal, Sequencial e de Cultura) para EXC, DEF, e Extrato do $\mathrm{BH}$; e à correlação dos dados climáticos com a produtividade da cana-de-açúcar. Os dados de chuva e temperatura, período de 30 anos, foram fornecidos pelo IAPAR. Os dados de produção da cana-de-açúcar foram obtidos por meio do PAM/
IBGE para um período de 17 anos para todos os municípios paranaenses e por meio dos anuários de produção agrícola do IBGE para um período de 25 anos apenas para os municípios de Cambé e Mirador. Os dados de produtividade foram submetidos à verificação da tendência tecnológica. Os dados de clima foram mensurados por meio das médias aritméticas do período, anual e mensal e juntamente com os dados de produtividade efetuaram-se análises dos desvios em relação à média e análise de correlação e regressão. Por meio desses procedimentos identificou-se que a evolução espaço-temporal da produtividade nos anos de 1990 a 2006, analisada de quatro em quatro anos em escala de mesorregiões, microrregiões e municípios, apresentaram maiores produtividades no ano de 1998 seguido de 2002. As médias das produtividades foram de 82,4 ton/ ha em Cambé e de 76,2 ton/ha em Mirador. As médias de chuvas foram de 1604,0 mm em Cambé e de $1485,0 \mathrm{~mm}$ em Mirador. As temperaturas médias variaram de $21,0^{\circ} \mathrm{C}$ em Cambé e de $22,2^{\circ}$ C em Mirador. Com a análise dos desvios em relação à média obteve-se para Cambé, que o percentual de anos com desvios coincidentes entre a variável hídrica (chuva e EXC) versus produtividade esteve entre $66,0 \%$ a $76 \%$. E para a DEF versus produtividade o percentual foi de $36,0 \%$ a 44,0\%. Em Mirador esses valores ficaram entre $40,0 \%$ a $60,0 \%$ para a variável hídrica e produtividade e entre $28,0 \%$ a $48,0 \%$ para DEF e produtividade. A correlação entre os dados das variáveis analisadas foi significativa ao nível de $5 \%$ e $10 \%$ para: chuva e produtividade; DEF no estádio de maturação (BH Sequencial) e produtividade; EXC e DEF no estádio de desenvolvimento ( $\mathrm{BH}$ de Cultura); temperatura na série temporal estudada em anos de La Niña e em anos ENOS (BH Cultura) em Cambé; em Mirador a correlação significativa para EXC do BH Sequencial Decendial para o período de vinte e cinco anos e para DEF do BH Cultura em anos de La Niña no estádio de desenvolvimento. A temperatura apresentou correlação significativa na série temporal (BH Cultura) no estádio de Estabelecimento e para anos ENOS (BH de Cultura) nos estádio de Estabelecimento em EL Niño e desenvolvimento em La Niña. Assim, anos com 
Teses de Doutorado e Dissertações de Mestrado

chuva acima da média (EI Niño) e anos com chuva na média do período (Neutro), apresentam correlação pouco significativa com a produtividade da cana-de-açúcar que em anos com chuva abaixo da média (La Niña).

\section{Contribuição ao estudo da vegetação da porção leste da Ilha de Marajó}

\section{Carlos Tadeu de Carvalho Gamba Orientador:}

A manutenção dos ecossistemas florestais da Amazônia é, sem dúvida, de suma importância para preservação da biodiversidade do planeta. Utilizar e avaliar dados de última geração que forneçam informações sobre estes ecossistemas torna-se então fundamental para o gerenciamento dos mesmos. Projeto pioneiro realizado na década de 1970, o RADAM teve como objetivo levantar, a partir de imagens de RADAR obtidas na banda $X$, informações sobre os recursos naturais da Amazônia. O avanço dos sistemas sensores baseados nas tecnologias de RADAR (Radio Detection and Ranging), com a introdução de plataformas capazes de imagear a superfície em comprimentos de onda maiores e em mais de uma polarização, trouxe uma nova perspectiva no campo de estudo destes recursos. Este trabalho emergiu a partir da constatação da necessidade, e possibilidade, de se obter informações mais precisas e atualizadas sobre o ambiente amazônico, levando em conta, inclusive, a velocidade das transformações que recaem sobre essa região. O objetivo primário do estudo foi analisar o potencial das imagens produzidas pelos radares de abertura sintética (SAR) nas bandas $L$ e nas polarizações HH, HV e VV, na avaliação de tipologias vegetais da porção leste da Ilha de Marajó. Entendemos que essa pequena parcela do ambiente amazônico nos cede uma chave de padrões de classificação que podem ser replicados em outras regiões da Amazônia Legal, ou mesmo, em novos projetos de mapeamento similares ao RADAM. Os resultados obtidos por meio de análises das imagens de radar e através do estudo de diversas propostas de classificação fitogeográfica, evidenciaram um alto potencial de utilização destes recursos, bem como a possibilidade de avançarmos na escala de análise, produzindo mapeamentos de maior detalhe e mais abrangentes do ponto de vista das classes vegetais. A tecnologia para incrementar o mapeamento da região amazônica, de forma mais criteriosa e precisa, já existe há algum tempo e está disponível às instituições nacionais. Dar esse salto, importantíssimo para o conhecimento, preservação e monitoramento daquele que é considerado hoje o bioma mais importante do mundo, só depende de uma mudança nos critérios e de uma atualização das ferramentas usadas até o momento.

\section{O microclima de uma vereda degradada: estudo de caso no Parque Estadual Veredas do Peruaçu - MG}

Sergio Serafini Junior

Orientador: Ailton Luchiari

O Bioma Cerrado, ao longo da história de ocupação pelo homem, vem sendo explorado em detrimento da redução de sua biodiversidade. Dentre as várias características típicas da vegetação do cerrado, nesta tese, um maior destaque é dado às veredas que se alinham ao sistema hidrográfico acompanhando seu traçado e formando um corredor de cobertura vegetal de porte arbóreo, muito utilizado pela fauna local como fonte de alimentação, reprodução e abrigo, favorecendo o fluxo gênico local, como parte do processo natural de manutenção dos ecossistemas ali presente formadores do Bioma Cerrado. Em vista da importância da preservação ambiental do cerrado, foi criado o Parque Estadual Veredas do Peruaçu que está localizado na região norte de Minas Gerais, onde também, estão instaladas propriedades rurais que concentram suas atividades na exploração agrícola e pecuária. Neste contexto, o próprio rio Peruaçu configurase como o limite geográfico entre esta Unidade de Conservação e as propriedades rurais ali próximas que, frequentemente, o ultrapassam como forma de ampliação de suas áreas 
produtivas, além da caça e corte de madeira para produção de carvão, comprometendo a preservação dos ambientes de veredas ali existentes, modificando também as características microclimáticas daquele ambiente, verificada na área de estudo, através da coleta de dados, quando verificou-se que aqueles ambientes modificados pela ação antrópica apresentaram temperatura do ar $\left({ }^{\circ} \mathrm{C}\right)$ mais altas e umidade relativa do ar (\%) menor.

\section{Contribuição ao estudo da vegetação da porção leste da Ilha de Marajó}

Carlos Tadeu de Carvalho Gamba

\section{Orientador: Ailton Luchiari}

A manutenção dos ecossistemas florestais da Amazônia é, sem dúvida, de suma importância para preservação da biodiversidade do planeta. Utilizar e avaliar dados de última geração que forneçam informações sobre estes ecossistemas torna-se então fundamental para o gerenciamento dos mesmos. Projeto pioneiro realizado na década de 1970, o RADAM teve como objetivo levantar, a partir de imagens de RADAR obtidas na banda $X$, informações sobre os recursos naturais da Amazônia. O avanço dos sistemas sensores baseados nas tecnologias de RADAR (Radio Detection and Ranging), com a introdução de plataformas capazes de imagear a superfície em comprimentos de onda maiores e em mais de uma polarização, trouxe uma nova perspectiva no campo de estudo destes recursos. Este trabalho emergiu a partir da constatação da necessidade, e possibilidade, de se obter informações mais precisas e atualizadas sobre o ambiente amazônico, levando em conta, inclusive, a velocidade das transformações que recaem sobre essa região. O objetivo primário do estudo foi analisar o potencial das imagens produzidas pelos radares de abertura sintética (SAR) nas bandas $L$ e nas polarizações HH, HV e VV, na avaliação de tipologias vegetais da porção leste da Ilha de Marajó. Entendemos que essa pequena parcela do ambiente amazônico nos cede uma chave de padrões de classificação que podem ser replicados em outras regiões da Amazônia Legal, ou mesmo, em novos projetos de mapeamento similares ao RADAM. Os resultados obtidos por meio de análises das imagens de radar e através do estudo de diversas propostas de classificação fitogeográfica, evidenciaram um alto potencial de utilização destes recursos, bem como a possibilidade de avançarmos na escala de análise, produzindo mapeamentos de maior detalhe e mais abrangentes do ponto de vista das classes vegetais. A tecnologia para incrementar o mapeamento da região amazônica, de forma mais criteriosa e precisa, já existe há algum tempo e está disponível às instituições nacionais. Dar esse salto, importantíssimo para o conhecimento, preservação e monitoramento daquele que é considerado hoje o bioma mais importante do mundo, só depende de uma mudança nos critérios e de uma atualização das ferramentas usadas até o momento.

\section{Território, cidade e rede: o papel de Rondonópolis na expansão da soja no Cerrado Mato-Grossense}

\author{
Elias da Silva \\ Orientador: Júlio César Suziki
}

A presente pesquisa tem como objetivo analisar o papel da cidade de Rondonópolis no processo em rede de expansão territorial da soja no cerrado mato-grossense, particularmente no sudeste do estado, desde suas pré-condições à atualidade, buscando como pressupostos dos processos constituidores a herança histórico/territorial, econômica e localizacional que vem se estruturando ao longo de mais de 3 décadas, iniciado no período de 1970, mais especificamente, a partir de meados deste, qual ocorreram as mudanças político/territorial/local/global mediadas pelas mudanças socioeconômicas brasileiras. Assim, a tese está fundada no período em que se deu a divisão do estado, cuja situação colocou Rondonópolis e região em posição privilegiada, passando de área secundária a 
Teses de Doutorado e Dissertações de Mestrado

prioritária para a soja, situação cujas bases podem ser atribuídas à herança histórica de apropriação territorial e produção agropecuária iniciada no período 1950/1960. Nesse sentido, justifica-se nosso caminho teórico-metodológico que nos permitiu ver e compreender melhor a realidade atual, qual seja, o da busca da herança histórico/ geográfica na produção da localização, visando os processos localmente (re)construídos em suas especificidades. Deve-se considerar o papel do Estado como imprescindível no processo de desenvolvimento da soja: sua introdução, consolidação e diversificação, seja produzindo o território e/ou como parceiro no processo de construção das infraestruturas e constituição desse ambiente produtivo. 0 impulso modernizador e urbanizador inaugurado com chegada da soja, a partir de suas pré-condições, ao atribuir posição de destaque a Rondonópolis no contexto da modernização agrária do cerrado mato-grossense, a partir da sua região, fez surgir cidades a partir da soja, especialmente Primavera do Leste e Campo Verde, como dois fortes e característicos exemplos que representam seu surto modernizador cidade/campo, resultando no processo de valorização territorial, cuja paisagem, sobretudo a urbana, demonstra de forma característica as contradições socioespaciais da lógica da acumulação capitalista com base na propriedade da terra, concomitantemente à exclusão de grande parte da população do direito desta. O processo, assim, é marcado pela (re) estruturação desta cidade no âmbito de atendimento da demanda de produção e expansão da soja numa atribuição de progressiva importância local, regional e até extraregional, destacando como situações inerentes ao seu papel: o mercado de trabalho, a pesquisa e tecnologia, a indústria, comércio e serviços especializados, o marketing como discurso, as atribuições em perspectivas e a gestão política da localização, esta última, perpassando as demais, uma vez que significa a força da elite local, de forma que Rondonópolis está sendo promovida cabeça de rede urbana desse modelo econômico implantado no cerrado mato-grossense conhecido como complexo da soja. A gestão política da localização, na atualidade e, em perspectiva, é exercida no sentido do adensamento da logística dos transportes rodo/ferroviário com todo o incremento de investimentos que já são vislumbrados.

\section{Metodologia de classificação de imagens multiespectrais aplicada ao mapeamento do uso da terra e cobertura vegetal na Amazônia: exemplo de caso na região de São Félix do Xingu, sul do Pará.}

\author{
Fernando Shinji Kawakubo \\ Orientador: Ailton Luchiari
}

Este trabalho apresenta uma metodologia de classificação de imagens multiespectrais aplicada a análise e mapeamento da evolução do uso da terra/cobertura vegetal em São Félix do Xingu, Sul do Pará. Imagens frações representando as proporções de sombra, vegetação e solo foram estimadas a partir das bandas 1 a 5 e 7 do Landsat-5 TM e relacionadas com as estruturas das classes de uso da terra/cobertura vegetal. As imagens frações geradas do modelo linear de mistura espectral foram importantes para reduzir a massa de dados e ao mesmo tempo realçar alvos de interesse na imagem. A banda do infravermelho próximo (TM-4) foi importante para realçar áreas de queimadas. A classificação adotada foi divida em etapas combinando técnica de segmentação por crescimento de regiões e uso de máscaras. Por meio da máscara foi possível restringir o processo de segmentação em regiões préestabelecidas com o intuito de adquirir um melhor particionamento da imagem. Adotando este procedimento, ao invés de realizar uma única segmentação para mapear todas as classes em uma única vez, foram realizadas várias segmentações ao longo das etapas. As regiões segmentadas foram agrupadas com um classificador não-supervionado batizado de ISOSEG. Os resultados mostram que a metodologia é bastante eficiente. A matriz de erro gerada para a classificação de 2008 apontou que as confusões mais freqüentes ocorreram entre as classes que apresentaram em certas localidades proporções de misturas parecidas: Capoeira e 
Campo/Pastagem-2; Campo/Pastagem-1 e Campo/Pastagem-2; Queimada-1 e Queimada-2; Solo Exposto e Campo/Pastagem-1. Considerando nove classes, o índice Kappa atingiu 0,58, o que representa um valor de concordância classificada como moderada. Quando o numero de classes foi reduzido para 6 , agrupando as classes que apresentaram as maiores confusões, o índice Kappa subiu para 0,80, atingindo um valor de concordância quase perfeita. A comparação dos resultados das classificações de 1987, 1992, 2000 e 2008 juntamente com a analise de dados auxiliares permitiu traçar um modelo de evolução do desmatamento e do uso da terra para São Félix do Xingu. $O$ intenso desmatamento observado principalmente a partir de 2000 foi relacionado com o incremento da atividade pecuária, sendo São Félix do Xingu o município que detém atualmente o segundo maior rebanho bovino do País.

\section{Dissertações de Mestrado}

\section{Bonito para quem? Um estudo sobre um destino turístico no Mato Grosso do Sul: situação atual e perspectivas, Bonito, MS, Brasil}

\author{
Marcelo Teixeira César de Oliveira \\ Orientador: Sueli Angelo Furlan
}

A região de Bonito, localizada no estado do Mato Grosso do Sul, tornou-se a mais visitada como turismo de natureza nos últimos anos no Brasil. O objetivo principal desta pesquisa foi o turismo praticado na região desde o seu surgimento na década de 1980 e avaliar alguns aspectos da sua gestão ambiental de sua implantação a seu desenvolvimento. O estudo abrangeu os municípios de Bonito, Jardim e Bodoquena onde a atividade turística se desenvolve. Bonito foi apresentado através da propaganda das operadoras e na mídia como um destino de ecoturismo. O crescimento deste produto de turismo nos últimos 20 anos, a facilitação dos acessos, a expansão dos meios de hospedagem e a recente construção do aeroporto sinalizam para um fluxo em massa que agrava um quadro preocupante que pode ampliar conflitos já existentes entre conservacionistas e o turismo. A experiência somada de 25 anos acompanhando diretamente a atividade de ecoturismo junto a grupos em atividades dirigidas em várias áreas naturais do Brasil serviu como referencial de partida para condução deste trabalho. As viagens a Bonito foram realizadas em quatro períodos nos anos de 1989, 1990, 2000, 2004 num total de 21 dias. Com auxílio de uma base teórica advinda de várias áreas do conhecimento trabalhouse com dados coletados em campo, com os registros de notas e de fotografias. Esses dados serviram de base para a confecção do questionário de entrevistas (semiestruturadas). Os depoimentos foram colhidos de pessoas-chave que testemunharam o processo de implantação do turismo na região. A coleta de depoimentos ocorreu entre os meses de março e abril de 2010. Os dados levantados foram sistematizados e agrupados por categorias que continham informações do histórico, dos recursos naturais, infraestrutura e serviços, mídia, marketing e promoção, pesquisa na região, visitação, educação ambiental, conflitos e gestão ambiental. Esses dados compuseram um quadro histórico dos acontecimentos e foram usados, posteriormente, para compor a análise através de três indicadores - conservação, sustentabilidade ambiental e interpretação ambiental. $\mathrm{O}$ intuito foi o de verificar se cabe o uso do rótulo eco para o turismo desenvolvido na região. Concluiu-se que a conservação está garantida, mas ressalta-se que foi observado um efeito bolha já que muitos se apresentaram como cenários apenas ao redor dos atrativos turísticos naturais, desvinculados da realidade do entorno. Os mecanismos de gestão não asseguraram a sustentabilidade ambiental da atividade, já que careceram de compromissos mais amplos com relação às responsabilidades socioambientais. A atividade de interpretação ambiental ainda é pouco presente nos programas de turismo pesquisados. Como tal, estas atividades não devem ser promovidas como 
Teses de Doutorado e Dissertações de Mestrado

ecoturismo. Vale nota, no entanto, o fato de que foram identificadas algumas propriedades onde foram aplicados os princípios da conservação, sustentabilidade ambiental e as atividades de interpretação

\section{Opções de adaptação às mudanças do clima para a bacia do rio Aricanduva}

\author{
Gustavo Costa Moreira da Silva
}

Orientador: Maria Elisa Siqueira Silva

Como as mudanças climáticas globais vêm ocorrendo de maneira acelerada, o agravamento dos problemas característicos de regiões com grande concentração de população só tende a aumentar. Este estudo tem como objetivos secundários, a avaliação das principais vulnerabilidades existentes na Bacia Hidrológica do Rio Aricanduva e, que se agravarão com as mudanças climáticas, principalmente com respeito aos recursos hídricos, saúde humana e desastres naturais, através de avaliação interdisciplinar, envolvendo as questões sociais e ambientais que interagem na dinâmica das regiões urbanas brasileiras, chegando ao objetivo principal que é identificar as opções de adaptação em função da vulnerabilidade, propondo assim, ações privadas e políticas públicas, sem negligenciar as importantes interações entre as opções de adaptação e a mitigação. Para chegar ao resultado final foram analisadas as projeções climáticas pra o Século XXI através de cinco modelos regionais para três cenários de emissões, sendo eles, o A2 (altas emissões), o B2 (baixas emissões) e o A1B (estabilização das emissões), assim como os dados climatológicos da cidade e da área da bacia para se determinar a evolução do clima. Após essas análises o objetivo foi de identificar os impactos que a região da bacia sofrer em relação às essas mudanças no clima. Para se identificar as atuais vulnerabilidades foram coletados dados socioeconômicos e ambientais, sendo dados brutos e georreferenciados que serão cruzados e identificados em gráficos, tabelas e mapas. Identificadas as áreas e setores vulneráveis da Bacia do Aricanduva, será possível analisar e expor as opções de adaptação, propondo assim, ações privadas e políticas públicas de acordo com os impactos das mudanças climáticas que agravarão essas vulnerabilidades.

\section{Conectividade insular: um estudo da presença de Spartina alterniflora nas Ilhas de Cananéia e Comprida}

Jonathan Américo Nascimento Ferreira

Orientador: Sueli Angelo Furlan

Os manguezais do Sistema Lagunar CananéiaIguape, no extremo sul do litoral do estado de São Paulo, possuem, em suas franjas mais externas, a presença da gramínea Spartina alterniflora, que exerce papel fundamental na fixação de sedimentos que poderão se tornar áreas de propagação do mangue. Pioneiras na região alagada do mangue, a Spartina segura e prepara o substrato para as plântulas de espécies de mangue se instaurarem. O mapeamento da Spartina alterniflora nas Ilhas de Cananéia e Comprida, onde estas ilhas margeiam o mesmo canal lagunar, possibilitou identificar as áreas propensas ao seu crescimento. Os pontos de baixa energia do fluxo de água do canal mostraram-se favoráveis ao surgimento de bancos de Spartina. A troca contínua de sedimentos e nutrientes existentes em um ambiente lagunar rico em manguezais, associada à grande capacidade de captação e fixação da Spartina, resultou em um estudo de conectividade entre duas ilhas.

\section{Das leituras da paisagem e sua representação cartográfica: as unidades da paisagem do município de Ubatuba - SP.}

$$
\text { Kelly Cristina de Mello }
$$

$$
\text { Orientador: Sueli Angelo Furlan }
$$

No âmbito da Geografia, verifica-se que o estudo da paisagem é de fundamental importância para a compreensão dos fenômenos resultantes da relação entre a dinâmica social e a dinâmica da natureza, permitindo avaliar os resultados da 
relação entre o tempo/espaço social e o tempo/ espaço natural. Este trabalho de pesquisa trata da identificação de Unidades de Paisagem no município de Ubatuba (SP), partindo da avaliação da paisagem através do estudo das condicionantes do meio físico, social e cultural, destacando-se também a importância da espacialização para construção da síntese, representada por meio da Cartografia Ambiental. O referencial teórico baseou-se na abordagem sistêmica, preconizada na Teoria Geral dos Sistemas. Os procedimentos operacionais e metodológicos desenvolveram-se em etapas, desde a pesquisa bibliográfica, trabalho de campo, sistematização de dados, caracterização e mapeamentos. O modo de análise buscou ser integrador, contendo elementos norteadores, estabelecimento de escalas espaciais de abordagem, definição e mensuração de áreas denotando formas sustentáveis de utilização, em aspectos históricos, espaciais e ecológicos.

\section{Práticas de pesquisa de campo com comunidades tradicionais: contribuições para a gestão participativa do Arquipélago de Ilhabela - SP}

Mariana Soares de Almeida Pirró

\section{Orientador: Sueli Angelo Furlan}

O presente trabalho vem contribuir com a abordagem acadêmica dos processos participativos para envolvimento de populações tradicionais no planejamento e gestão de áreas protegidas insulares, trabalhando com populações caiçaras que habitam ilhas e trazendo reflexões por experiências com pesquisa, educação popular e gestão participativa no Arquipélago de Ilhabela. São apresentados os referenciais teóricos no campo da geografia e antropologia marítima, a abordagem de planejamento e ordenamento territorial, e questões sobre áreas protegidas e políticas de inserção social. Buscou-se fazer uma construção da concepção de pesquisa-açãoparticipativa a partir da educação popular, apresentando formas de trabalho e abordagens do pesquisador em campo para trabalho com comunidades tradicionais e trazendo ferramentas de pesquisa e diagnóstico participativo para estudo das comunidades e levantamento de população. Por fim são apresentados dados e informações sobre as Comunidades Tradicionais Caiçaras do Arquipélago de Ilhabela, obtidos a partir da aplicação das ferramentas descritas e do conhecimento dos sujeitos trabalhados, demonstrando que informações necessárias para discutir as relações das comunidades com as unidades de conservação podem ser obtidas a partir de práticas de pesquisa de campo. Então são trazidos argumentos para subsidiar a reflexão e planejamento da gestão do Parque Estadual de Ilhabela, tendo como foco o reconhecimento da presença da população tradicional no interior e entorno da unidade e pensando a inserção dessa comunidade no manejo e gestão participativa da natureza protegida. Para concluir demonstra-se que, com este tipo de abordagem, é possível obter dados fundamentais para pensar o ordenamento ambiental e territorial; além deste se configurar como uma maneira de envolvimento, aproximação e troca de informação. Porém, o processo de apropriação e protagonismo de populações locais na gestão de seus lugares requerem um longo caminho, com trabalhos complementares que fomentem a participação.

\section{Estudo de dinâmicas de paisagens no baixo curso do Rio Ipojuca, Pernambuco: potencial para sustentabilidade socioeconômica e cultural da região}

\author{
Paulo Alves Silva Filho
}

Orientador: Yuri Tavares Rocha

Um dos grandes desafios na esfera do planejamento e gestão ambiental reside na necessidade de superar as distintas formas de regionalização. Desde os primórdios são inúmeros os esforços de unificação de bases que permitam uma gestão conciliatória de limites e intervenções no espaço. $O$ presente trabalho tem como objetivo analisar a dinâmica de paisagens no Baixo Curso do Rio Ipojuca (Pernambuco), possibilitando a identificação de diferentes níveis de complexidade para o planejamento e gestão dessa área objeto, 
Teses de Doutorado e Dissertações de Mestrado

a partir das transformações e permanências de atividades econômicas responsáveis pela dinâmica sócio-espacial da área. O recorte aqui adotado tem sua escolha justificada por pontos de pressão que caracterizam significativos impactos na dinâmica da bacia em sua totalidade, sendo estes: a presença do Complexo Portuário-Industrial de Suape e a existência secular de atividades em larga escala relacionadas à produção e transformação da cana-de-açúcar. O entendimento de paisagem neste trabalho se dá de forma sistêmica e integrada, pela qual os constituintes abióticos, bióticos e antrópicos são compreendidos de forma interdependente. A análise dessas paisagens possibilitou uma aproximação de sua atual configuração, assim como projetaram-se tendências no sentido das alteração mediante alteração, introdução ou ainda modificação de seu padrão por meio de grandes empreendimentos estatais e privados. O Complexo Industrial Portuário de Suape recebe uma atenção maior, já que apresenta uma um contexto em termos de planejamento totalmente diferenciado do seu entorno, a partir da verificação de uma regionalização que privilegia aspectos socioeconômicos e coloca os elementos / recursos naturais em segundo plano. A sobreposição desse quadro junto à uma análise regional por meio de dados estatísticos apontam para um direcionamento de total modificação da região, demandando urgentemente novas políticas de planejamento voltadas para a geração de um quadro de sustentabilidade socioeconômica e cultural.

\section{Infraestrutura de dados espaciais em unidades de conservação: uma proposta para disseminação dainformação geográfica do Parque Estadual de Intervales - SP}

Eduardo Tomio Nakamura

Orientador:Alfredo Pereira de Queiroz Filho

Esse trabalho apresenta uma proposta de Infraestrutura de Dados Espaciais de nível organizacional para o Parque Estadual de
Intervales-SP, que visa compartilhar suas informações geográficas com a sociedade em geral. Nos processos de elaboração da IDE são discutidas questões como interoperabilidade, padronização, metadados, especificação de serviços geográficos e o relacionamento dos nós das Infraestrutura de Dados Espaciais que vão permitir a disseminação da informação geográfica de fácil acesso a usuários externos. Os procedimentos, benefícios e limitações são listados e problematizados de forma que demonstrem as etapas necessárias na elaboração da Infraestrutura de Dados Espaciais de nível organizacional para uma Unidade de Conservação. Conclui-se que uma Infraestrutura de Dados Espaciais depende de variáveis administrativas, culturais, técnicas e financeiras, o que leva a uma proposta de implementação por estágios. Também são elaboradas críticas aos recursos existentes e sugestões para melhorias e estudos futuros.

\section{Estudo microclimático do ambiente de cavernas, Parque Estadual Intervales, SP}

\author{
Bárbara Nazaré Rocha \\ Orientador: Emerson Galvani
}

A proteção ambiental dos recursos geológicos é uma questão com crescente interesse. A exploração de cavernas é uma das formas de turismo associada a recursos geológicos mais difundida. Por isso, deve-se conhecer suas características ambientais, tais como os climáticas, para definir estratégias de gestão e conservação ambiental associadas a seu uso turístico. Assim, o objetivo geral da pesquisa é detectar as principais alterações microclimáticas ocorridas no ambiente cavernícola em decorrência das visitas turísticas no interior das grutas do PEI, SP. Como objetivos específicos, definiu-se: caracterizar o microclima do ambiente de caverna em condições naturais e elencar características físicas da cavidade que influenciem em seu microclima. A metodologia consistiu na coleta de dados de temperatura e umidade relativa do ar de nove cavidades com registradores autônomos. Também foram registrados os valores de $\mathrm{CO} 2$. A variação 
dos atributos do clima foi analisada em situação natural e na presença de visitantes. Os resultados mostram que o microclima das cavernas tende à estabilidade dos valores de temperatura do ar e apresentam umidade relativa do ar e concentração de gás carbônico elevada. Cavernas com rios caudalosos e claraboias não apresentam impacto em sua atmosfera decorrente do turismo, pois as trocas gasosas com o meio externo são facilitadas. Nas grutas secas e afóticas, com entradas e corredores estreitos, o microclima tende à estabilidade, estando mais sujeito a impactos, especialmente elevações na temperatura do ar. 0 uso de carbureteira também gera acréscimos significativos nas concentrações de gás carbônico.

\section{Geomorfologia da planície fluvial do rio Pinheiros entre os bairros de Pinheiros, Butantã e Cidade Jardim, São Paulo (SP)}

Rodolfo Alves da Luz

Orientador: Cleide Rodrigues

Na presente pesquisa investiga-se a geomorfologia da planície fluvial do rio Pinheiros entre os bairros de Pinheiros, Butantã e Cidade Jardim, na cidade de São Paulo. Para tal, propõe-se uma carta geomorfológica de detalhe deste setor da planície na escala de 1:20.000, confeccionada a partir de pesquisa arquivística prévia e, principalmente, de fotografias aéreas e de mapas antigos. A análise da carta e a sua correlação com informações sedimentológicas e estratigráficas encontradas, principalmente, em recentes relatórios de engenharia para a construção do Metrô de São Paulo, permitem a caracterização do sistema fluvial deste setor do rio Pinheiros, bem como de parte da morfodinâmica atuante no sistema antes da perturbação antrópica de alto impacto decorrente da urbanização que ali se instalou a partir da década de 1930. A pesquisa permitiu também a interpretação de uma provável sequência de eventos geomorfológicos atuantes no setor estudado durante o Pleistoceno Superior e o Holoceno. Parâmetros morfométricos tais como índice de sinuosidade de canais e paleocanais e largura da planície no trecho estudado evidenciaram aspectos da influência da estrutura geológica em sua evolução. O reconhecimento de sistemas geomorfológicos em seu estágio préperturbação antrópica é essencial para a compreensão dos processos atuais, principalmente em meios intensamente modificados como as áreas urbanas. A pesquisa apresenta então este tipo de reconhecimento, colaborando assim na compreensão dos processos antecedentes às grandes rupturas que se instalam no sistema a partir das ações antrópicas na superfície.

\section{Contribuições da geografia ao licenciamento e ao estudo de impacto ambiental}

\author{
Hélio Garcia Paes
}

Orientador: Luis Antonio Bittar Venturi

Este trabalho tem o objetivo principal de demonstrar o potencial de atuação dos geógrafos na elaboração de Estudos de Impacto Ambiental (EIAs), a partir da formação multidisciplinar deste profissional, alcançada pelo seu preparo teóricometodológico, técnico, sua formação científica e sua postura crítica, as quais embasam sua participação em diferentes relatórios contidos dentro dos EIAs, bem como na coordenação dos mesmos, ou na produção de mapas que acompanham os diagnósticos. São também demonstrados exemplos práticos dos relatórios passíveis de serem executados pelos geógrafos, além de ter sido realizado um levantamento quantitativo e qualitativo da participação deste profissional neste ramo de atividade, por meio da análise de quarenta EIAs, inseridos no período de 2000 a 2009, tendo como espacialização, o Estado de São Paulo. Assim, objetivou-se também, que este trabalho pudesse servir de subsídio para quem pretende ingressar nesta carreira, indicando caminhos e demonstrando a diversidade de contribuições a serem oferecidas pelos geógrafos.

\section{Ilhas do litoral norte do estado de São} Paulo: paisagem e conservação

Ricardo Sartorello 
Teses de Doutorado e Dissertações de Mestrado

\section{Orientador: Sueli Angelo Furlan}

Para se chegar a modelos mais precisos de unidades de conservação devemos pensar a importância do desenvolvimento do conhecimento sobre a dinâmica insular. O principal objetivo da pesquisa foi avaliar a relação entre as fisionomias vegetais encontradas em oito ilhas do litoral norte paulista e alguns de seus aspectos estruturais, com área, forma e distância da costa (isolamento), utilizando como indicadores espécies vegetais de diferentes estágios de sucessão ecológica, em matas de encosta. Foram selecionadas oito ilhas com diferentes áreas, formas e distâncias da costa: ilhas do Prumirim, Porcos Pequena, Comprida, das Couves (Ubatuba), ilhas do Mar Virado, Tamanduá e Maranduba (Caraguatatuba) e ilha da Vitória (Ilhabela). O trabalho foi desenvolvido com em três etapas: primeiro a apreensão sobre a área de estudo, por meio da produção de bases e produtos cartográficos em escala 1:10.000, incluindo um mapeamento das fisionomias vegetais com base em ortofotos e imagens de satélite; segundo, a produção de dados primários, por meio de estudo sobre as métricas de paisagem para todas a ilhas do litoral norte, avaliando e área, forma e isolamento. o levantamento bibliográfico das espécies arbóreas que ocorrem nas ilhas, e um trabalho de campo focal na ilha do Prumirim; e terceiro, o mapeamento de unidades de paisagens das ilhas e elaboração de proposta para o planejamento de seu uso testando três variáveis, conservação, assentamento e turismo. Dentre os resultados destacamos: os mapas de vegetação, com os quais foi possível mensurar e comparar os tipos de fisionomias que cobrem as ilhas; a análise da forma, do tamanho e isolamento da ilhas do litoral norte, que resultou em dados mais precisos sobre esses ambientes insulares e trouxe parâmetros de comparação para as ilhas selecionadas, no contexto da região costeira; o levantamento de espécies, revelando que das treze mais frequentes nas ilhas slecionadas, sete são pioneiras, características de formações secundárias, evidenciando o aspecto geral de mata alterada em estágio de regeneração e ressaltando da importância dessas espécies generalistastas; a alta correlação entre o número de espécies em cada ilha com a área e forma, um dos preceitos da teoria biogeográfica de ilhas; e por último, a partir da delimitação das unidades de paisagens, a proposta de uso para as ilhas na qual, em síntese, identificamos um forte potencial para a conservação e o turismo ordenado, equação da qual acreditamos, depender o futuro das ilhas. Esperamos que este trabalho traga além de um aprofundamento sobre o conhecimento desses ambientes insulares, uma inquietação sobre as formas de se pensar a conservação não só de ilhas, mas de tantos outros ambientes isolados, como os fragmentos continentais da mata Atlântica.

\section{Cartografia tátil escolar: experiências com a construção de materiais didáticos e com a formação continuada de professores}

\author{
Waldirene Ribeiro do Carmo
}

\section{Orientador: Regina Araujo de Almeida}

O presente trabalho aborda a Cartografia Tátil Escolar, com destaque para a análise e discussão da importância do mapa tátil na formação continuada de professores, assim como sua aplicação no ensino de Geografia e Cartografia para pessoas com deficiência visual, em escolas de ensino fundamental e médio. Foi incluído um estudo sobre a produção e uso de materiais didáticos táteis, de forma a orientar professores e prepará-los para o ensino de Geografia voltado a estudantes com deficiência visual. A Cartografia Escolar está na interface entre a Cartografia, a Educação e a Geografia, na busca de desenvolver metodologias de ensino/aprendizagem do mapa e de construção do espaço pela criança. As atividades cartográficas nas aulas de Geografia são importantes para auxiliar análises e para desenvolver habilidades de observação, percepção e representação do espaço. Daí a importância do manuseio, reprodução, interpretação e construção de mapas. Os PCNs (Parâmetros Curriculares Nacionais) do Brasil destacam a importância da Cartografia Escolar ao apontar como um dos objetivos do ensino da Geografia no ensino fundamental saber utilizar a linguagem 
cartográfica para obter informações e representar a espacialidade dos fenômenos geográficos. Os PCNs também sugerem blocos temáticos, listando conteúdos que incluem a leitura e compreensão das informações expressas em linguagem cartográfica. As representações gráficas que são apreendidas essencialmente pela visão, também podem ser percebidas pelo tato, desde que construídas com este objetivo. A inclusão de estudantes com deficiência visual em classes regulares requer que as escolas possam disponibilizar materiais cartográficos adaptados ao tato e professores preparados para lidar com esta realidade. Este trabalho apresenta e discute experiências com cursos de formação continuada de professores e sua aplicação no ensino de Cartografia na educação básica, particularmente para pessoas com deficiência visual, tanto em escolas especializadas no atendimento destes estudantes, quanto em escolas em geral. Fez parte da pesquisa, uma descrição e análise dos cursos e oficinas sobre cartografia tátil e ensino de geografia para pessoas com deficiência visual, realizados entre agosto de 2006 e outubro de 2009, no Brasil e no Chile, dentro de um projeto internacional desenvolvido em conjunto pela Universidade de São Paulo e Universidade Tecnológica Metropolitana. Durante estes cursos percebeu-se a dificuldade dos professores em trabalhar a cartografia em sala de aula, particularmente, a cartografia tátil. Os cursos de formação continuada significam um avanço na qualidade de ensino de estudantes com deficiência visual e a difusão de técnicas de construção de materiais didáticos adaptados, assim como orientações para sua utilização são renovações pedagógicas significativas que ampliam o uso dos materiais para todos os estudantes.

\section{Sistema de Informações Geográficas destinado ao planejamento da atividade apícola no assentamento 'Padre Josimo Tavares'- PA}

Rodrigo Veneziani de Paula

Orientador: Jorge Gustavo da Graca Raffo
Atualmente, a apicultura é aproveitada de forma econômica pelo homem na polinização das plantações, assim como na produção de própolis, geléia real, apitoxina e o mais conhecido e explorado pelo homem, o mel. A apicultura tem se consolidado como uma das atividades mais importantes do ponto de vista econômico, social e ambiental, uma vez que ao empregar mão-deobra familiar e proporcionar geração de fluxo de renda, reduz a dependência dos produtos agrícolas de subsistência e favorece a fixação do homem no campo. Todavia, sem utilizar nenhum recurso computacional ou uma metodologia sistemática, os apicultores escolhem o local para instalar suas colméias, seja dentro dos perímetros da propriedade, ou numa região geográfica mais abrangente, como, por exemplo, um município. 0 Sistema de Informações Geográficas (SIG) é uma ferramenta computacional, resultado de combinação da Cartografia com a Informática, que permite efetuar análise espacial e cruzamento de informações espaciais de uma forma, antes, quase impossível de se pensar, pelo enorme esforço requerido, tempo exigido e o custo resultante. Este trabalho visa criar um SIG destinado a escolha do local que possa otimizar a produção apícola. Como conseqüência desta metodologia, surge também um melhoramento na polinização de zonas escolhidas, afetando e acelerando o processo de recuperação de áreas degradadas. As técnicas de manejo apícola desenvolvidas têm conseqüências econômicas e sociais para as populações envolvidas, como é o caso do exemplo utilizado neste trabalho, assentamento rural Padre Josimo Tavares.

\section{Mapeamento de biótipos: instrumento para o fomento da qualidade ambiental}

\author{
Marcos Antonio de Mello \\ Orientador: Sueli Angelo Furlan
}

O mapeamento de biótopos pode ser considerado como uma ação prática do planejamento da paisagem. O método surgiu para conduzir a análise e o entendimento das características estruturais e funcionais da paisagem, demonstrando 
Teses de Doutorado e Dissertações de Mestrado

identidades ecológicas entre porções territoriais mediante o estudo/diagnóstico dos componentes biofísicos, antrópicos e das inter-relações existentes. Além do estabelecimento de indicativos, qualitativos e quantitativos que denotem e mensurem parâmetros de qualidade ambiental. Destarte, a realização deste mapeamento visa o estabelecimento de bases para o planejamento territorial, tendo a mensuração da qualidade ambiental como elemento primordial para sua efetivação, justificando assim, a aplicabilidade da referida metodologia, inspirada em experiências européias, onde tais mapeamentos são realizados em escalas de detalhe. O referencial teórico adotado parte de uma abordagem geossistêmica, onde a paisagem pode ser representada por um conjunto de biótopos, denotando a integração de variáveis naturais e antrópicas, configuradas em unidades homogêneas. Os procedimentos teóricos e operacionais atendem a variadas etapas, constituídas em trabalhos de levantamentos de campo, sistematização de dados, caracterização e mapeamentos. Os resultados obtidos, segundo preceitos teóricos, metodológicos e procedimentos propostos, foram organizados em forma de dados alfanuméricos e espaciais, inseridos em banco de dados com interfaces com SIGs. Assim, foram geradas cartas temáticas em escalas de detalhe $(1: 10000)$ cartografando e correlacionando as informações produzidas, traduzidas em parâmetros de qualidade ambiental, com destaque para a cobertura vegetal.

\section{Técnicas cartográficas e aerotogramétricas no estudo da erosão: alta bacia do Ribeirão Araguá - São Pedro e Charqueada / SP}

Marcos Roberto Pinheiro

\section{Orientador: Rosely Pacheco Dias Ferreira}

Este trabalho teve como objetivo fazer um inventário das feições erosivas lineares da alta bacia do ribeirão Araquá, municípios de São Pedro e Charqueada/SP, com base em técnicas cartográficas e aerofotogramétricas analógicas e digitais. O levantamento foi realizado em 2 escalas de abordagem diferentes: 1:50.000 (semidetalhe) e 1:15.000 (detalhe). Na escala de semidetalhe, produziu-se uma carta hipsométrica, uma carta clinográfica e um mapa morfológico, onde foram representadas as feições erosivas. Esses produtos, aliados com as informações sobre solos, litologia e o uso da terra, deram origem ao mapa morfopedológico da sub-bacia. Com base nesse mapa, foi definida a sub-bacia do Córrego do Querosene para o estudo em escala de detalhe. Na sub-bacia do Córrego do Querosene foram produzidas as cartas hipsométrica e clinográfica e os mapas de morfologia do relevo, solos, uso da terra e formas erosivas lineares. O levantamento do uso da terra e das formas erosivas lineares foi realizado com base em fotografias de 4 períodos diferentes, 1962 $(1: 25.000), 1978(1: 35.000), 1995$ (1:25.000) e 2006 (1:30.000). Esse diagnóstico possibilitou realizar correlações das formas erosivas com as características do meio físico, o que deu origem a um mapa de suscetibilidade à erosão, além de ter permitido uma avaliação da evolução temporal das feições. Os resultados mostraram que a área atingida por sulcos diminuiu $38,18 \%$ no período de 1962 a 2009. Em contrapartida, as afetadas por linhas de pisoteio subiram $137 \%$. No mesmo período, o número de ravinas aumentou em $87,5 \%$, e as voçorocas cerca de $300 \%$. Os dados mostraram também que as ravinas e voçorocas se instalaram preferencialmente em setores côncavos das vertentes, com declividades acima de $10 \%$, principalmente, e em áreas como solos muito arenosos, profundos, homogêneos, permeáveis e cobertos por pastagens ou vegetação ciliar. As técnicas de interpretação e restituição aerofotogramétricas digitais se mostraram muito superiores às analógicas, embora o processo digital tenha se mostrado mais moroso que o analógico. As técnicas digitais permitiram a correção de grande parte das distorções geométricas das fotos, facilitando, dessa forma, as medidas das ravinas e voçorocas.

\section{A modernização do Vale do Jequitinhonha mineiro e o processo de formação dotrabalhador "boia-fria" em suas}




\section{condições regionais de mobilização do trabalho}

Ana Carolina Gonçalves Leite

Orientador: Heinz Dieter Heidemann

Nessa dissertação, procuramos discutir o processo de territorialização do que veio a ser instituído em Minas Gerais, a partir da década de 1960, como o Vale do Jequitinhonha. Abordamos esse processo de territorialização em seus contornos coloniais, uma vez que seu sentido conformou as relações sociais de produção particulares que passaram a viabilizar a acumulação de capital com a generalização do trabalho livre. Nesse contexto, instaurou-se no nordeste mineiro uma dinâmica regional de expansão da fazenda agropecuária, fundada na relação de agregação de lavradores, na qual o controle territorial, por meio da possibilidade do emprego direto da violência, condicionou a subordinação do trabalho. Essas relações sociais de produção regionais, por sua vez, passaram a ser objeto da intervenção estatal a partir das décadas de 1960 e 1970. Abordamos essa intervenção como parte do processo de modernização retardatária, movido nacionalmente como esforço de industrialização e de superação de formas de acumulação tidas como arcaicas. Modernização que, por meio da imposição de uma forma determinada de desenvolvimento, fundada na consolidação da propriedade da terra e na formação do trabalhador assalariado, deveria alimentar a indústria em formação no centro-sul do país. Por fim, partimos do processo de expropriação dos antigos lavradores do Vale do Jequitinhonha para observar a transformação dos mesmos em trabalhadores bóias-frias, em condições definidas pelos limites da modernização, que explicita seu caráter crítico.

\section{Élisée Reclus e a geografia da Colômbia: cartografia de uma interseção.}

\section{David Alejandro Ramirez Palacios}

Orientador: Manoel Fernandes de Souza Neto
O seguinte ensaio interessa-se pelos momentos de conjunção entre a obra do geógrafo e cartógrafo anarquista francês Élisée Reclus (1830-1905) e um país chamado Colômbia, em cujas montanhas chegou a morar por um par de anos quando ainda tinha por nome Nova Granada e incluía o Panamá e sobre o qual escreveu em diferentes ocasiões. Procura avançar na compreensão das lógicas dominantes do projeto intelectual deste autor mediante o mapeamento do jogo de referências desatado por ele nos capítulos «Colômbia» (1893) e «Panamá» (1891) da sua Nova Geografia Universal, tentando identificar e organizar seus elementos, procurando obter algum tipo de retorno em termos de filosofia política. Considera especialmente a participação do geógrafo e cartógrafo colombiano Francisco Javier Vergara y Velasco, interlocutor e colaborador de Reclus no processo de criação desses capítulos por meio do estudo da correspondência inédita dirigida a ele pelo francês, formulando a partir da mesma algumas questões sobre o funcionamento do eurocentrismo. Aspira, enfim, deixar preparado o terreno para uma imersão mais vertical nestes textos, centrada na procura da formação territorial da Colômbia.

\section{Globalização na escola, para além de um conteúdo}

Edna Celeste Vieira Bonassi

Orientador: Nidia Nacib Pontuschka

Esta dissertação trata do ensino da globalização, enquanto conteúdo no último ano do Ensino Fundamental. A pesquisa envida nos caminhos de compreensão da globalização no campo teórico, mas enfocada principalmente em sua materialização no lugar de vivência do aluno, expresso no cotidiano e as relações dialéticas aí geradas a fim de oportunizar condições de contexto dessa temática para encaminhamento do tema nas aulas de Geografia. O nascedouro desta proposta ocorreu em função de contradições e paradoxos no comportamento dos alunos em relação à posse e uso de aparelhos tecnológicos de última geração, e também, das dificuldades, 
Teses de Doutorado e Dissertações de Mestrado

enfrentadas por nós professores, no ensino desse conteúdo. Assim, o objetivo da pesquisa está direcionado para a possibilidade de contextualizar - conteúdo da globalização na perspectiva dialética, considerando as variáveis que se the constituem, as dimensões: tecnológica, cultural, política, econômica e social, manifestas e imbricadas no cotidiano. Antes, porém é dedicado um espaço de compreensão do jovem e sua condição no contexto da e na globalização, se perfazendo no lugar do vivido, do cotidiano. O jovem, neste início de século, vive em presentes perpétuos, fragmentados pelas imagens, signos e significados; o tempo presente é um momento aparentemente único, descolado de um passado e supostamente sem vínculo com o futuro. A juventude, enquanto condição está equacionada nos moldes da racionalidade econômica e disponibilizada à globalização através dos sentidos orientados para o mercado de consumo neste momento sócio histórico e cultural, quando os signos, produtos e cultura, tomam a forma de mercadoria e delineiam comportamentos que sugerem o imediatismo e a efemeridade. Demonstramos as relações do contexto através das respostas dadas pelos alunos, seja no questionário de perguntas fechadas ou abertas. Para tanto, se fez necessária a compreensão de elementos constitutivos da globalização, no caso, destaca-se a tecnologia e o consumo, este com conotação cultural, em decorrência da ênfase dada às mercadorias-signos, imagens e bens que, em geral, ganham novos significados no processo, assim como a cidadania atrelada aos direitos de consumo a serviço do capitalismo. Tem-se nessa dialética a relação ensino aprendizagem da e na globalização objetivado no desenvolvimento formativo do aluno. Nesse sentido, destacamos as entrevistas com os professores, a fim de apurar como é articulado o conteúdo da globalização, no último ano do Ensino Fundamental, na intenção de evidenciar as dificuldades desses profissionais com relação ao tema para um posicionamento mediante às questões relevantes e propor sugestões. O encaminhamento, por sua vez, se constitui como eixo de sugestões possíveis para compor a articulação do conteúdo da globalização no movimento dialético das dimensões que the perfazem, a fim de favorecer o ensino e aprendizagem desse tema tão complexo. Faz-se necessário ainda tornar significativo o conteúdo a partir da realidade vivida por esses jovens e contribuir para um modo de pensar mais consciente e formador do aluno no desenvolvimento da cidadania.

\section{Estado de São Paulo: análise geográfica da educação básica e mapeamento temático}

Jorge Luiz Prando

Orientador: Marcello Martinelli

Esta dissertação intenciona realizar uma análise geográfica com o apoio da cartografia temática acerca da qualidade da educação básica pública do Estado de São Paulo. Objetivamos adicionar conhecimentos, materiais e informações sobre a atual condição da escola e contribuir com o futuro planejamento da educação. Esse trabalho enfatiza a ótica da dinâmica regional, a dicotomia entre o desempenho educacional das pequenas e grandes cidades do Estado, a fim de com analisar e entender porque as cidades do interior paulista vêm obtendo ultimamente desempenhos mais satisfatórios em indicadores educacionais em relação à capital e os municípios metropolitanos de São Paulo. Há ainda a preocupação em utilizar a cartografia temática para contribuir com a própria Geografia; então, produzimos mapas temáticos desenvolvidos a partir de indicadores educacionais dos anos de 2000, 2002, 2004 e 2006, além disso há um layout complementar em coluna destes mapas, que procurou demonstrar a evolução dos indicadores através do tempo. Então, utilizamos um rico acervo de dados estatísticos e também análises críticas a respeito do tema estudado, evidenciando a importância da linguagem gráfica para a Geografia, a Educação e outras ciências.

\section{A cartografia ambiental de síntese: procedimentos e aplicações para omunicípio de Limeira - SP}

Fredy Ravazzi Lima 


\section{Orientador: Marcello Martinelli}

O município de Limeira SP enfrentou um crescimento urbano intenso e desordenado, após a segunda metade do século $X X$, oriundo dos incentivos públicos de descentralização industrial da capital paulista, que provocou grandes problemas socioambientais. $O$ presente estudo procura analisar as fragilidades e potencialidades da organização do espaço em Limeira através da metodologia da Cartografia Ambiental de Síntese, pois esta possibilita a delimitação de unidades individualizadas da paisagem a partir da síntese dos atributos físicos e sociais presentes no espaço. Para tanto, foi realizado um levantamento bibliográfico dos principais conceitos e metodologias dos estudos ambientais na Geografia, dando destaque à Cartografia e aos novos instrumentos de coleta e manipulação de dados espaciais. Em seguida, foram coletadas informações sobre o município através de pesquisa bibliográfica, imagens de satélite e trabalhos de campo. Estas informações foram organizadas no software SPRING para a confecção dos mapas temáticos e do mapa ambiental de síntese. De posse do mapa final foi possível analisar cada unidade de paisagem isoladamente segundo seus atributos, podendo servir de suporte a outros estudos no município e para a administração pública a fim de subsidiar um planejamento territorial mais compatível com a realidade local.

Os Centros Logísticos e Industriais Aduaneiros e a atual indústria paulista

\author{
Lucas Ferreira Rosa Penha \\ Orientador: Maria Mónica Arroyo
}

Frente a um período no qual a escala de ação para muitos agentes sociais sobretudo as empresas hegemônicas no mercado globalizado corresponde ao mundo, os territórios nacionais são mobilizados e transformados de maneira a viabilizar a organização e eficiência dos circuitos espaciais produtivos internacionalizados. A criação dos Centros Logísticos e Industriais Aduaneiros (CLIAs) é, além de muitas outras, uma dessas adaptações do território. São recintos que exercem função aduaneira de despacho/admissão de mercadorias importadas ou a serem exportadas, mas que se situam fora da zona primária de portos e aeroportos, constituindo-se como alternativa às alfândegas tradicionais para a importação ou exportação de mercadorias. São, então, novos objetos geográficos que aumentam a porosidade territorial brasileira criando caminhos mais fluidos para as trocas internacionais, principalmente para alguns circuitos espaciais produtivos. A presença deles no estado de São Paulo liga-se diretamente ao processo de industrialização desse território uma vez que são utilizados em grande parte pela indústria química e pela indústria automotiva. Torna-se importante, assim, a individualização das relações estabelecidas entre os CLIAs e as indústrias às quais são funcionais. Por fim, além da participação dos CLIAs nesses circuitos espaciais produtivos, também podem implicar diferentes relações com o lugar onde são instalados, criando modalidades diversas de integração ao território verticais e horizontais. É justamente o entendimento dessa dinâmica territorial complexa que constitui o objetivo central do presente trabalho.

\section{As enchentes do rio Aricanduva (MSP) e a construção de conhecimentos no ensino de Geografia}

\author{
Marcia Yoko Kobayashi \\ Orientador: Vanderli Custódio
}

O objetivo geral da pesquisa é verificar até que ponto a Geografia ensinada em escolas cuja comunidade é afetada por enchentes tem realizado a leitura do espaço de vivência dos alunos e uma aprendizagem significativa. O trabalho de campo foi realizado em cinco escolas públicas (estaduais e municipais) situadas no entorno do rio Aricanduva, no baixo e médio cursos do rio, na área de maior inundação. Foram entrevistados Diretores, Coordenadores Pedagógicos, Professores e alunos da $6^{a}$ série do ensino fundamental. Os questionários (abertos) versam sobre a construção do conhecimento em Geografia 
Teses de Doutorado e Dissertações de Mestrado

e a noção de enchentes. Também foram analisadas as Propostas Curriculares Oficiais e os livros didáticos (adotados nas escolas). Observou-se que há um descompasso, entre o que se intenciona ensinar, a concepção de ensino e de Geografia e o que se aprende na disciplina. De um lado os professores (Propostas Curriculares e os livros didáticos) têm uma concepção que se preocupa com a realidade e o desenvolvimento do pensamento crítico, por outro lado; os alunos, possuem uma concepção da disciplina e da escola ligada à localização, ao mercado de trabalho e ao conhecimento enciclopédico. Em relação às enchentes prevalecem, entre os entrevistados, explicações destituídas de elaboração científica, embora, entre os professores, haja alguma compreensão da questão das inundações urbanas enquanto produto do processo de urbanização, como pensamos deveria ser. Os resultados demonstram a relevância da concepção de ensino baseada na construção de conhecimentos com referência no conhecimento cotidiano e situado no espaço vivido dos alunos.

\section{As cidades médias e a reestruturação da rede urbana amazônica: a experiência de Marabá no Sudeste paraense}

\author{
Rovaine Ribeiro \\ Orientador: Hérvi Émilien René Théry
}

Ao tratarmos da temática da urbanização, e neste caso, da urbanização na Amazônia, devemos levar em conta suas peculiaridades. As cidades devem ser entendidas a partir da maneira como se inserem, em maior ou menor grau na divisão do trabalho, e como historicamente foram afetadas pela divisão inter-regional do trabalho. (SANTOS, 2005) Assim, voltamos nosso olhar para a importância assumida pela cidade de Marabá no sudeste do Pará, tendo em vista sua centralidade na dinâmica de reestruturação socioespacial da região amazônica. Duas questões centrais norteiam esse trabalho: a) qual a importância exercida pela cidade de Marabá, enquanto uma cidade média, na rede urbana e no processo da reestruturação produtiva e espacial, da região amazônica? b) que elementos contribuem para que a cidade de Marabá se torne central nesse processo de reestruturação regional? Dessa forma, buscamos compreender, como, nesse processo de reestruturação da região amazônica, a cidade de Marabá, foi assumindo relevância na dinâmica urbana do sudeste paraense. Entrementes, essa dinâmica urbana regional, nos remete à investigação das possíveis centralidades que algumas cidades da região vêm assumindo nas redes de circulação do território, a partir da reestruturação produtiva regional. Finalmente, nossas preocupações se apresentam como pontos de partida para o entendimento desse conjunto de relações desencadeadas no âmbito da rede urbana regional, em que as especificidades das cidades na Amazônia, a exemplo de Marabá, acabam sendo fundamentais para a compreensão desse processo.

\section{A nova ordenação territorial das finanças no Brasil}

Clarisse Coutinho Ribeiro

\section{Orientador: Wanderley Messias da Costa}

Esta pesquisa aborda a relação entre território e finanças. O objetivo é analisar a nova ordenação territorial das finanças no Brasil, entre 1996 e 2006, como esta ocorreu, quais foram os seus principais fatores de formação e suas conseqüências. A metodologia utilizada, pelo lado teórico, baseia-se na abordagem do David Harvey sobre os ajustes temporal e espacial, e ordenação espaçotemporal e na teoria Pós-keynesiana sobre finanças regionais. Pelo lado empírico, utiliza-se análises estatísticas do índice de concentração Herfindahl-Hirschman (IHH) e taxas de crescimento acumulado, bem como a análise de cartografia temática digital. A pesquisa mostrou que a nova ordenação territorial das finanças ocorreu sobretudo devido ao grande crescimento e expansão territorial das atividades de intermediação financeira. Sendo assim, os seus principais fatores de formação foram: a abertura financeira da década de 1990, a reestruturação do sistema bancário nacional, estabilidade da 
moeda, o aumento da demanda financeira regional de baixo volume e o avanço do meio técnicocientífico-informacional. As principais conseqüências foram: a mudança na estrutura de composição do Sistema Financeiro Nacional, que passou a ter a atividade de intermediação financeira como principal atividade financeira do país e apesar da redução da concentração das finanças, esta não descentralizou as mesmas, como também não implicou na redução da concentração econômica do Brasil.

\section{Parque Nacional do Jaú, Unidade de Conservação e Patrimônio Natural Mundial na Amazônia Brasileira: a articulação de instrumentos permite melhor proteção?}

\section{Fabiana Cunha da Silva}

Orientador: Néli Aparecida de Mello Théri

O Parque Nacional do Jaú unidade de conservação de proteção integral protegida pelo SNUC (Sistema Nacional de Unidades de Conservação da Natureza) localiza-se, aproximadamente, $200 \mathrm{~km}$ a noroeste de Manaus e está inserido dentro dos limites territoriais dos municípios de Barcelos e Novo Airão, no estado do Amazonas. Sendo o maior Parque Nacional do Brasil com 2.272.000 hectares, cobrindo a segunda maior extensão de florestas tropicais úmidas contínuas do mundo na Amazônia, foi criado com o objetivo de proteger a bacia hidrográfica do Rio Negro, sua biodiversidade e seus recursos naturais. Reconhecido por paisagens notáveis e de beleza natural, por importantes processos ecológicos e biológicos relacionados à conservação da biodiversidade, e por ser detentor de importantes formações naturais relevantes tanto para a Ciência quanto à História da Humanidade, o PNJ foi selecionado como área de proteção do patrimônio natural da Humanidade pela Convenção da UNESCO (Organização das Nações Unidas para a Educação, Ciência e Cultura). No ano de 1993 é estabelecido um convênio de cogestão do PNJ entre o IBAMA (Instituto Brasileiro de Meio Ambiente e Recursos Naturais Renováveis) e a Fundação Vitória Amazônica (FVA), responsável pela elaboração do Plano de Manejo do Parque, cuja adoção de uma postura de envolver os moradores no planejamento, nas ações de manejo, criando espaços de discussão e socialização de experiências, possibilitou a consolidação da UC, definindo, assim, normas para o acesso e utilização dos recursos naturais (previstos no SNUC) vinculadas às necessidades de sobrevivência da população tradicional residente no Parque.

\section{Metropolização e segregações urbanas em Campo Limpo Paulista - SP}

\author{
Juliana Andrade Moura
}

\section{Orientador: Júlio César Suzuki}

Este trabalho tem como objetivo analisar de que maneira o município de Campo Limpo Paulista tem sido historicamente atingido pelos processos de modernização capitalista a partir do avanço da metrópole de São Paulo em direção ao seu entorno. Trata-se de compreender as especificidades da produção do espaço urbano em relação ao processo de metropolização. Campo Limpo por volta do ano de 1950 era considerado um pequeno povoado-estação do cinturão caipira, após deu origem ao modesto subúrbio industrial e residencial, tornando-se, mais recentemente, mais um dos espaços de reprodução periférica metropolitana. A industrialização e a urbanização possibilitadas e direcionadas por seus tentáculos - a Estrada de Ferro Santos-Jundiaí em 1881, depois as rodovias Anhanguera (1948) e Máximo Zamboto (1971) têm aglutinado mais fortemente novos lugares, contribuindo para a desagregação da unidade espacial interna do município, onde se tem verificado dinâmicas de autosegregação dos ricos vindos de São Paulo a ocupar as chácaras urbanas da Estância Figueira Branca e tem segregado os pobres entre seus iguais, no Conjunto Habitacional São José, além de ser um município receptor da dispersão industrial.

\section{A nova geografia militar: logística, estratégia e inteligência}

Filipe Giuseppe Dal Bo Ribeiro 
Teses de Doutorado e Dissertações de Mestrado

\section{Orientador: André Roberto Martin}

O presente trabalho tem como propósito estabelecer parâmetros de um campo pouco estudado pela ciência geográfica, a geografia militar. O conceito da geografia militar está relacionado com aspecto histórico de cada lugar e não está relacionado a uma escola de pensamento específica, não só a escola de pensamento geográfico, mas às escolas de pensamento marciais, portanto o propósito central é aprimorar e expandir o arcabouço teórico e metodológico da própria geografia. Não se trata aqui de realizar uma história da geografia militar, mas o presente trabalho tem como finalidade demonstrar o papel da geografia como aspecto mais concreto do fenômeno da guerra, da logística, da estratégia e da inteligência. Os temas estratégicos, embora pouco freqüentes na pesquisa geográfica brasileira ultimamente, são cada vez mais comuns em outras áreas do conhecimento, notadamente entre economistas, administradores, e claro, cientistas políticos. A importância de estudarmos a geografia sobre estes aspectos nos permite detectar se a evolução desta ciência influenciou nas concepções da tática e da estratégia; a correspondente relação entre geoestratégia e geopolítica; analisar conflitos específicos como a guerrilha, o terrorismo, a guerra nuclear, a guerra tática e confrontos de outras ordens. A geografia militar está relacionada com a condução das operações militares. Por outro lado, a geopolítica está mais relacionada às estratégias, por ser mais ideológica do que prática, portanto a geografia militar é a prática que viabiliza a estratégia. Por fim, será feita uma análise na nova geografia militar empregada pelo novo imperialismo mundial.

O álibi cultural: novas formas para a valorização e reprodução do espaço na metrópole contemporânea

Júlio Cesar ferreira Santos

Orientador: Ana Fani Alessandri carlos
A (re)produção das metrópoles para a venda no mercado mundial ocorre através da produção de novas formas espaciais associadas à urbanização contemporânea. Até então reconhecidamente espaço produzido pela indústria, agora a metrópole tende a conformar-se pela dispersão relativa da atividade produtiva. No bojo desse movimento, novos processos e estratégias são engendrados, voltados à reestruturação urbana, reproduzindo a metrópole de acordo com novas estratégias que apontam para a produção do Centro, ora em deterioração, como nova centralidade. Estas estratégias apontam para a recuperação de áreas urbanas degradadas, de modo a trazer de volta aos centros ou outras áreas em vias de revitalização as classes sociais com maior poder aquisitivo. Para isso, neste momento, a cultura é instrumentalizada como produto e lógica potencializada por uma ideologia desenvolvimentista. Assim, o objeto de nossa pesquisa consiste no estudo das políticas espaciais voltadas à revitalização de centros urbanos, políticas que atuam sob o discurso culturalista articuladas pelo Estado e pelo capital para a superação das barreiras existentes à valorização do valor e à circulação do capital. Neste sentido, dá-se a relação entre o Político e o econômico no processo de produção de novos espaços, utilizando-se de ideologias que ganham materialidade nas novas formas e relações engendradas na área central da metrópole. Dessa forma, nosso objetivo principal é discutir os termos nos quais a cultura aparece no interior do processo de (re)produção do espaço urbano a partir do Centro. Temos então como hipótese o seguinte: esses empreendimentos apoiados em um álibi cultural que criam marcos nas novas paisagens de poder e de dinheiro que se constituem no Rio de Janeiro e em São Paulo são elementos-chave para decifrar a mudança estrutural pela qual passamos atualmente e, particularmente, um novo momento da urbanização brasileira. Imprescindível nesta empreitada é resgatar os fundamentos históricos do processo de urbanização do Rio de Janeiro, das origens à atualidade, tendo a Lapa como recorte privilegiado nesta análise. São Paulo insere-se nesta investigação ao final do trabalho através de um 
estudo sobre a revitalização da área conhecida como Cracolândia, na periferia do Centro. Colocase, então, a necessidade de um paralelo com São Paulo a fim de apontar tendência no movimento da reprodução hoje.

Os donos do campo e os donos da bola: alguns aspectos da globalização do futebol

\section{Paulo Miranda Favero}

\section{Orientador: André Roberto Martin}

Nesta pesquisa, proponho analisar o futebol a partir de três pontos de vista diferentes, mas que se complementam: a globalização, a geopolítica e a mercantilização. O futebol transformou-se em uma indústria $\mathrm{e}$, independentemente da habilidade dos jogadores dentro de campo, o poder econômico dita os rumos como o futebol vai se realizar como prática social e não há como fazer uma análise geográfica do futebol sem levar isso em conta. Em tempos de globalização, as mudanças ocorrem também no esporte, em todos os níveis, em todos os lugares, em escalas e proporções diferentes. A intenção deste trabalho é mostrar como ocorre a concentração do dinheiro em poucos clubes e revelar a transformação do jogador em mercadoria.

\section{O processo de conformação da periferia urbana no município de Guarulhos: os loteamentos periféricos como (re)produção de novas espacialidades e lugar de reprodução da força de trabalho}

\author{
Nilton César de Oliveira Gama \\ Orientador: Júlio César Suzuki
}

Esta pesquisa buscou analisar o processo de conformação da periferia urbana na zona leste do município de Guarulhos, considerando os loteamentos periféricos como acesso à moradia operária. Deste modo, a pesquisa toma como objeto central o padrão periférico de crescimento na conformação da periferia do município de Guarulhos. A produção doméstica como técnica de construção viabilizou a materialização da casa própria contribuindo para reprodução da força de trabalho. Para que os loteamentos pudessem existir o parcelamento das terras consideradas rurais foram destinadas ao parcelamento e colocadas a venda como lotes urbanos, possibilitando a extração da renda da terra. O espraiamento urbano da capital paulista em sentido à Guarulhos consolidaria anos mais tarde a Região Metropolitana. As implicações do processo de regionalização ou simplesmente, a estruturação da Grande São Paulo passou a determinar a reprodução do espaço periférico e a sujeição do seu planejamento aos interesses da capital. Assim, uma nova espacialidade urbana surge em Guarulhos determinada principalmente pelos loteamentos periféricos instalados ao longo da região leste do município e em torno de um dos mais significativos equipamentos urbanos da região metropolitana paulista: o Aeroporto Internacional de Cumbica/São Paulo.

\section{As geotecnologias como instrumento de gestão territorial integrada e participativa}

Vanessa Garcia Fravin

Orientador: Reinaldo Paul Pérez Machado

O presente trabalho apresenta formas contemporâneas da administração pública lidar com seu usuário final: os cidadãos. Discute o que existe de mais moderno em tecnologias de informação e comunicação para melhorar as condições de governabilidade, controle do território, aplicações de políticas de segurança, educação, saúde, habitação, etc. Esse tema é atualmente muito discutido no mundo e nesta pesquisa pretende-se incorporar à discussão os benefícios das Geotecnologias potencializando o governo. É perceptível que há um consenso sobre novos paradigmas na gestão pública neste início de milênio. Encontros mundiais, fóruns, elaboração de Agendas de Meio Ambiente, Habitação, etc. falam sobre os mesmos conceitos: gestão, planejamento estratégico, desenvolvimento sustentável, cidade sustentável, desenvolvimento local, participação e 
Teses de Doutorado e Dissertações de Mestrado

representação popular. Com o incremento do Geoprocessamento na gestão pública, os benefícios do gerenciamento de todas as áreas do município possibilitam um amplo e real diagnóstico da cidade, serve tanto no apoio às políticas públicas como na democratização da informação. A prestação de serviços de governo com apoio das tecnologias de informação e comunicação e a presença do governo-eletrônico é um processo que só avança e melhora, como uma empresa vai aperfeiçoando seu site, tornando-o mais dinâmico, mais completo, o governo nas suas diversas esferas vai ampliando cada vez mais suas interfaces com os cidadãos. Pode-se sentir isso à medida que mais procedimentos se tornam disponíveis no meio eletrônico, possibilitando que uma pessoa ou empresa tenha informações on line. A pesquisa mostrou que as inúmeras inovações tecnológicas estão de fato contribuindo para a melhora das gestões municipais, porém, poderiam melhorar ainda mais se existisse um direcionamento do Governo Federal para tal. A visualização do território com o geoprocessamento não é a solução mágica para os problemas das cidades, nem pretende substituir a sensibilidade dos técnicos, mas o diálogo travado através destas inovações é único e aponta para um futuro com maior participação popular.

\section{As propostas metodológicas para a cartografia ambiental: uma revisão}

\author{
Maria Cristina Salvadeo de Souza \\ Orientador: Marcello Martinelli
}

A temática ambiental tem despertado enorme interesse em diversos seguimentos da sociedade, especialmente de pesquisadores da área, que vêem contribuindo com a produção de inúmeras publicações. No entanto, a bibliografia produzida para a Cartografia Ambiental tem apresentado lacunas, principalmente no trato do embasamento das pesquisas com enfoque teórico-metodológico. Este trabalho revisa as propostas metodológicas elaboradas por André Journaux, Jean Tricart, Helmut Troppmair e Carlos Augusto de Figueiredo
Monteiro para o mapeamento ambiental. Trata inicialmente da conexão existente entre a Geografia, os estudos ambientais e a ciência cartográfica, que é a própria interface entre os dois primeiros, expondo, dentro de um contexto histórico, várias visões da relação sociedadenatureza. Adotamos uma postura fundamentada pelo construto do Geossistema e da Semiologia Gráfica para que as representações possam refletir o espaço geográfico como um todo indissociável de objetos e ações. Alguns critérios inerentes à cartografia também foram abordados, para que servissem de baliza ao estudo: o problema das ordens de grandeza; a questão do dinamismo do mundo real versus a condição estática dos mapas; a almejada síntese cartográfica, a qual consideramos ser a forma ideal para os mapas ambientais; e a busca por uma legenda significativa, que auxilie o usuário em desvendar o mapa.

\section{Educação ambiental por projetos - Água hoje e sempre: consumo sustentável. Secretaria de Estado da Educação 2004 a 2007}

Marlene Gardel

Orientador: Sonia Maria Vanzella Castelar

Este trabalho analisa a implementação do Projeto de Educação Ambiental Água hoje e sempre: consumo sustentável, de 2004 a 2007, pela Secretaria de Estado da Educação de São Paulo, por meio de ações de formação continuada e da publicação Água hoje e sempre: consumo sustentável. O objetivo central é investigar se os professores do ensino fundamental e médio desenvolveram projetos interdisciplinares, tendo como ponto de partida uma problemática local, integrando-a em um contexto da bacia hidrográfica onde se localiza o município da escola, refletindo sobre as questões socioambientais regionais e propondo, junto à comunidade escolar, soluções para transformar o ambiente escolar e o seu entorno. A análise do trabalho apoiou-se nas teorias críticas de currículo, nas teorias sobre o desenvolvimento de projetos interdisciplinares e 
de educação ambiental crítica. Foram aplicados e aferidos questionários de 180 Professores Coordenadores de Oficinas Pedagógicas (PCOP) das 89 Diretorias de Ensino e de 637 professores, pelo software da SE. Em um segundo momento optou-se por uma pesquisa qualitativa com entrevista de grupo com 11 professores. Quanto aos resultados obtidos, o trabalho com projetos promoveu a inclusão de problemática local, envolvimento da comunidade, proposta e/ou transformação local, tratamento inter/ multidisciplinar e mudança de atitude dos alunos, demonstrando que os objetivos do projeto foram alcançados. Ampliou-se a concepção de meio ambiente, a sensibilização e conscientização dos alunos, tornando-os mais responsáveis e protagonistas. Evidenciou-se, porém, que há resistência de professores e diretores para o trabalho com projetos em razão da falta de identidade profissional com a escola e o alunado, corroborada pelo currículo tradicional. Há necessidade de reformulação no currículo, na concepção de formação inicial e continuada dos professores para assegurar a inserção da educação ambiental na Educação Básica. 